\title{
Transcriptome Profiling of the Shoot and Root Tips of S562L, a Soybean GmCLAVATA 1 A Mutant
}

\author{
Saeid Mirzaei ${ }^{1,2}$, Jacqueline Batley', Brett J Ferguson', and Peter M Gresshoff ${ }^{*}$
}

${ }^{1}$ Centre of Excellence for Integrative Legume Research, School of Agriculture and Food Sciences, The University of Queensland, St Lucia, Brisbane QLD 4072, Australia; ${ }^{2}$ Present address: Department of Biotechnology, Institute of Science, High Technology and Environmental Sciences, Graduate University of Advanced Technology, Kerman, Iran

Received: March 20, 2014 / Accepted: April 6, 2014

\begin{abstract}
Plant shoot apical meristems (SAM) and root apical meristems (RAM) contain stem cells that form overall-plant architecture. Mechanisms acting in these regions keep a balance between the stem cell population and differentiation. These mechanisms are well-studied in Arabidopsis, but little is known in the legume soybean (Glycine max (L.) Merr.). In Arabidopsis, the Leucine-rich repeat (LRR) Receptor kinase CLAVATA1 (CLV1) is a crucial regulator of this process in the SAM. In soybean, the receptor most similar to ATCLV1 is GmNARK, which is involved in nodulation control. In contrast, the homeologous partner of GmNARK in soybean, called GmCLVIA, appears to have no function in 'Autoregulation of nodulation' (AON) a role in regulating shoot architecture in the SAM. Here, the transcriptome of the shoot and root tip areas of a chemically induced and TILLING-selected GmCLV1A missense mutant, S562L, and its wild type, cultivar Forrest, were analysed to identify genes which are affected by impaired function of GmCLVIA. Among the differentially expressed genes identified, many were categorised as having a role in receptor kinase activity, transcription or defense/ stress-response. Molecular categories over-represented in the shoot tip of the mutant include those involved in hormone biosynthesis/activity and secondary metabolism, signalling, photosynthesis, and transport. Functional categories including those involved in polyamine metabolism, nucleotide metabolism, RNA regulation, protein targeting and protein degradation were under-represented in the shoot tip of the mutant. In the root tip, categories associated with signal
\end{abstract}

* Corresponding author: p.gresshoff@uq.edu.au ling, transport, protein synthesis and metabolism were overrepresented in the mutant, while categories associated with cell wall degradation, stress, RNA regulation, protein degradation and targeting were under-represented in the mutant. Factors similar to Arabidopsis regulatory components are most likely functioning in specialised shoot structures in legumes. Furthermore, GmCLVIA may have an unexpected role in the regulation of flavonoid biosynthesis in soybean.

Keywords: Glycine max, legume, plant development, RAM, receptor kinase, RNAseq, SAM, symbiosis.

\section{Introduction}

Soybean (Glycine max (L.) Merr.), garden pea (Pisum sativum), common bean (Phaseolus vulgaris) and alfalfa/lucerne (Medicago sativa) are some of the important crops belonging to the legume family, which are second to the grasses in providing food for the world's population. One-third of all dietary protein and one-third of processed vegetable oil for human consumption are provided by grain legumes (Gepts et al., 2005; Graham and Vance, 2003).

Nitrogen is the most required nutrient of plants and enters into many biological molecules such as amino acids, proteins and nucleic acids. Although dinitrogen gas $\left(\mathrm{N}_{2}\right)$ forms a main part of the earth's atmospheric gas $(78.1 \%)$, it cannot be used by most of the plants, generating a global need for nitrogen-containing fertiliser. Leguminous plants, however, are able to use dinitrogen gas through a symbiotic association with soil bacteria, collec-
ATLOS Publishing, LP
This is an Open Access article distributed under the terms of the Creative Commons Attribution License (http://creativecommons.org/licenses/by/3.0/), which permits unrestricted use, distribution, and reproduction in any medium, provided the original work is properly cited. 
tively named rhizobia (Ferguson et al., 2003).

Apical meristems including those of the shoot (SAM) and root (RAM) are responsible for the aerial and underground organs of the plant, respectively (Stahl and Simon, 2010; Traas and Hamant, 2009). SAM and RAM are specialised regions containing stem cells, which allow plants to grow continuously throughout their life through the control of a pool of stem cells. Similar to animal stem cells, plant stem cells are capable of generating diverse tissues and renewing the stem cell population (Sharma et al., 2003).

Therefore, the major function of the SAM is to keep a dynamic balance between maintenance of the pluripotent stem cell population and the formation of new organs (leaves and flowers) and enables plants to grow and reproduce (Fletcher, 2002). Some pathways and regulatory mechanisms in this process have been identified through studies using the model plant Arabidopsis, a crucifer. Of particular significance is the role of the CLAVATA (CLV) signalling network to regulate the size of the stem cell reservoir in the SAM. Mutations in genes (like CLV1, CLV2 and CLV3) acting in the CLV network lead to the proliferation of undifferentiated cells in the SAM and the development of an abnormal apical meristem (Clark et al., 1993; 1997). Within this gene network, CLV1 encodes a leucine-rich repeat receptor kinase (LRR-RK) and plays a critical role in this pathway.

AtCLV1-like genes in soybean are GmNARK and GmCLV1A. GmNARK regulates nodulation through a mechanism called Autoregulation Of Nodulation (AON) (Searle et al., 2003) and GmCLVIA appears to have a function in the SAM (Mirzaei et al., 2014; submitted). However, to date, little is known about the 'CLV' network of soybean. Recently, through TILLING, an EMSinduced missense mutation in a putative S-glycosylation site (S562L) in GmCLV1 A was isolated (Batley et al., 2014; submitted). The mutant shows an alternative function from GmNARK and behaves as a loss-of-function allele. GmCLV1A lacks any measurable effect on nodulation despite sharing over $90 \%$ DNA sequence with GmNARK. The S562L mutation leads to severe nodal identity alterations in the basal parts of the emergent plant such as branching, as well as flower and pod abnormalities (Mirzaei et al., 2014; submitted).

Several methods are available to study gene expression, such as qRT-PCR, microarrays and high-throughput RNA sequencing (RNA-seq) (Ozsolak et al., 2009). qRT-PCR is utilised for studying a small number of genes and samples, microarrays are used for large scale gene expression studies (e.g., whole transcriptome), and RNA-seq also evaluates the whole transcriptome, but with less danger of confusing data caused by cross-hybridisation of related genes. In recent years, RNA-seq has been widely used for transcript profiling and gene discoveries in plant species including legumes, such as soybean (Hayashi et al., 2012; Libault et al., 2010; Reid et al., 2012).

In this study, we compared the transcriptome of the shoot and root tip of the S562L, Gmclv la mutant, and its wild type parent (cultivar Forrest) using RNA-seq. The CLC genomics workbench program was subsequently used to map the RNA-seq data to the soybean reference genome and determine the relative transcript abundance. The results provide further evidence to aid the understanding of meristem maintenance in soybean.

\section{Materials and Methods}

\section{Plant Growth Conditions}

Soybean (Glycine max (L. Merr.) wild type cv. Forrest and the EMS-induced and TILLING-selected missense mutant S562L were used for this experiment. For RNA-seq, seeds were surface-sterilised by immersion in $70 \%$ ethanol for $30 \mathrm{~s}$, then rinsed 5 times with sterile water, and were put between filter paper in sterile Petri dish and kept in a growth chamber at $25^{\circ} \mathrm{C}$ in dark conditions.

\section{Tissue Harvest}

Shoot tips ( $1 \mathrm{~mm}$ ) and root tips $(2 \mathrm{~mm})$ were harvested after 48 hours using a sterile scalpel and immediately frozen in liquid nitrogen. Shoot tips of plants 48-hours old were collected under the dissecting microscope after opening the cotyledon and removing the emerging leaves.

\section{RNA Sample Preparation and Library Construction}

For RNA-seq, total RNA was extracted from dissected shoot and root tips using the Qiagen RNeasy Minikit with on-column DNAse digestion according to the manufacturer's instructions (Qiagen, Maryland, USA). The Australian Genome Research Facility (AGRF) subsequently conducted cDNA library construction and RNA sequencing. cDNA libraries for plant transcriptome sequencing were constructed using the Illumina Truseq RNA kit according to Illumina protocols and RNA sequencing was performed using the Illumina HiSeq 2000 platform, with four multiplexed samples run on one flowcell lane generating $100 \mathrm{bp}$ single-end reads.

For qRT-PCR experiment, RNA was converted to CDNA in a 20- $\mu$ l reaction mixture containing $0.5 \mathrm{mM}$ deoxynucleoside triphosphates (dNTPs), $1 \mu \mathrm{l}$ of $50 \mu \mathrm{m}$ oligo(dT) primers, 40 unit of RNaseOUT (Invitrogen), $0.5 \mu \mathrm{g}$ of DNA-free RNA, $1 \mathrm{x}$ firststrand buffer (Invitrogen), $5 \mathrm{mM}$ dithiothreitol (DTT) and 100 units of SuperScript III reverse transcriptase (Invitrogen) at $50^{\circ} \mathrm{C}$ for $60 \mathrm{~min}$. Finally, cDNA was confirmed using $\mathrm{GmCons} 6$ primers (Libault et al., 2008) (Glyma 12g05510; F box protein family) and PCR.

\section{Quantitative Real Time PCR}

Primers used for quantitative real-time PCR were designed using the online primer design program, Primer 3 version 0.4 .0 (available at http://frodo.wi.mit.edu). Sequences from the soybean genome (Phytozome version 8.0; the United States Department of Energy Joint Genome Institute and Centre for Integrative Genomics; available at http://www.phytozome.net) were used for primer design. The sequences for forward and reverse primers for each gene are shown in Table 3 . To ensure that the primers were specific and produced only a single band, normal PCR was run using Forrest cDNA. All primer pairs were found to amplify a single product of the correct size.

The relative transcript abundance was detected using SYBR 
Green PCR Master Mix (Applied Biosystems) on an ABI 7900HT cycler (Applied Biosystems) in a 384-well plate. The 384-well plates were set up using an Eppendorf epMotion 5075 Robotic system and contained no template (water) control and reverse transcription negative (RT-) controls to verify genomic DNA contamination of the samples. All reactions were carried out in duplicate of one biological replicate. The qRT-PCR conditions used were as follows: initial denaturation of $95^{\circ} \mathrm{C}$ for $10 \mathrm{~min}$, then 45 cycles of $95^{\circ} \mathrm{C}$ for $15 \mathrm{sec}$ and $60^{\circ} \mathrm{C}$ for $1 \mathrm{~min}$ followed by a dissociation stage of $95^{\circ} \mathrm{C}$ for 2 mins to assess the specificity of the PCR. The expression level of the genes was normalised to the mRNA expression level of soybean GmCons6 (Libault et al., 2008) amplified by forward primer 5'-AAAGGTGAAATTGCCTCTTCC-3' and reverse primer 5'-CCCAAAGATCTGCCAAATGTA-3'. PCR efficiency for each sample was calculated using the LinRegPCR 7.5 program (Ramakers et al., 2003).

\section{Bioinformatics and Data Analysis of Sequencing Output}

The read quality score was determined using the FastX tool kit. Shoot and root read sequence data were mapped separately against the soybean genome (available at Phytozome; http:// www.phytozome.net/) using the CLC Genomics Workbench with the RNA-seq function and the mapping setting: minimum length fraction 0.9 , and minimum similarity fraction 0.8 . Relative transcript abundance was yielded in "Read Per Kilobase" of exon model Per Million mapped reads (RPKM) values. This value only uses the mapped reads and relative size of transcripts to determine expression level.

Differentially expressed genes were identified by comparing expression values between samples and using Kal's test (Kal et al., 1999) which considers proportions, rather than raw data. Genes were determined to be differentially expressed using thresholds of fold change $>=2$ with Kal's $Z$ test $p$-value $<0.05$.

\section{Results}

\section{Transcriptome Sequencing (RNA-seq) Outputs}

To help understand how GmCLV1 A affects the gene expression network in soybean, transcript profiles of the shoot and root tip of S562L Gmclv la mutant and wild type (Forrest) were compared at germination. One hundred (100) bp single-end sequence reads generated using an Illumina Hi-seq 2000 platform had a good quality (Phred quality score $\geq 32$; Figure 1). Results of mapping reads against the soybean reference genome (available at Phytozome; http://www.phytozome.net/) are summarised in Table 1. Overall a total of $84-87 \%$ of the reads from each sample uniquely mapped to the soybean genome, whereas $\sim 4 \%$ were non-specifically mapped.

\section{Transcriptomes of Wild Type Forrest and Mutant S562L Shoot Tips}

By having at least one read match, a total of 40,229 genes were expressed in the wild type shoot tip compared with 41,172 genes in the S562L shoot tip. Comparison of wild type and $S 562 L$ shoot tip genes expression value (RPKM) indicated that 631 genes had a differential transcript abundance (Kal's Z test; $P \leq 0.05)$. Around $71 \%$ of differentially expressed genes (448 genes) had significantly higher expression in the S562L shoot tip relative to the wild type, and $29 \%$ of differentially expressed genes (183 genes) genes had less expression. Of these, $277(\sim 62 \%)$ of the more-highly expressed genes had a fold change of two or greater, whereas $62(\sim 34 \%)$ lower-expressed genes had a fold change of two or greater. A subset of these differentially expressed genes, which were predicted to encode either protein kinases, transcription factors, protein binding, defense, stress response or catalytic activity, is presented in Table S1 [see additional file].

\section{Transcriptomes of wild type Forrest and Mutant S562L Root Tips}

A total of 40,460 genes were expressed in the wild type root tip compared with 40,714 genes in the $S 562 L$ root tip. Comparison of gene expression values in the wild type and $S 562 \mathrm{~L}$ root tips identified 1,204 genes that had differential transcript abundance $(P \leq 0.05)$. Around $64.5 \%$ of differentially expressed genes (777 genes) increased in expression in the S562L root tip relative to wild type and $35.5 \%$ of differentially expressed genes (427 genes) decreased. Four hundred and forty six (446: $\sim 58 \%$ ) of these more-highly expressed genes had a fold change of two or greater and 140 ( 33\%) lower-expressed genes had a fold change of two or greater. A subset of these differentially expressed genes, with activities such as protein kinase and signalling activity, transcription factor activity, protein binding, defence and stress response, and catalytic activity are presented in Table S2 [see additional file].

Table 1. Mapping RNA sequencing reads to the Glycine max genome.

\begin{tabular}{|c|c|c|c|c|}
\hline & Wild type shoot tip & S562L shoot tip & Wild type root tip & S562L root tip \\
\hline Total reads & $39,284,610$ & $44,789,650$ & $34,169,345$ & $33,856,295$ \\
\hline \multirow[t]{2}{*}{$\begin{array}{l}\text { Uniquely mapped } \\
\text { reads }\end{array}$} & $34,063,809$ & $38,886,356$ & $28,999,578$ & $28,343,248$ \\
\hline & $87 \%$ & $87 \%$ & $85 \%$ & $84 \%$ \\
\hline \multirow[t]{2}{*}{$\begin{array}{l}\text { Non-specifically } \\
\text { mapped reads }\end{array}$} & $1,639,245$ & $1,879,153$ & $1,450,399$ & $1,400,816$ \\
\hline & $4 \%$ & $4 \%$ & $4 \%$ & $4 \%$ \\
\hline \multirow[t]{2}{*}{ Un-m apped reads } & $3,581,556$ & $4,024,141$ & $3,719,369$ & $4,112,231$ \\
\hline & $9 \%$ & $9 \%$ & $11 \%$ & $12 \%$ \\
\hline
\end{tabular}


Quality score for forrest shoot tip (Top) and SS62L shoot tip (bottom)

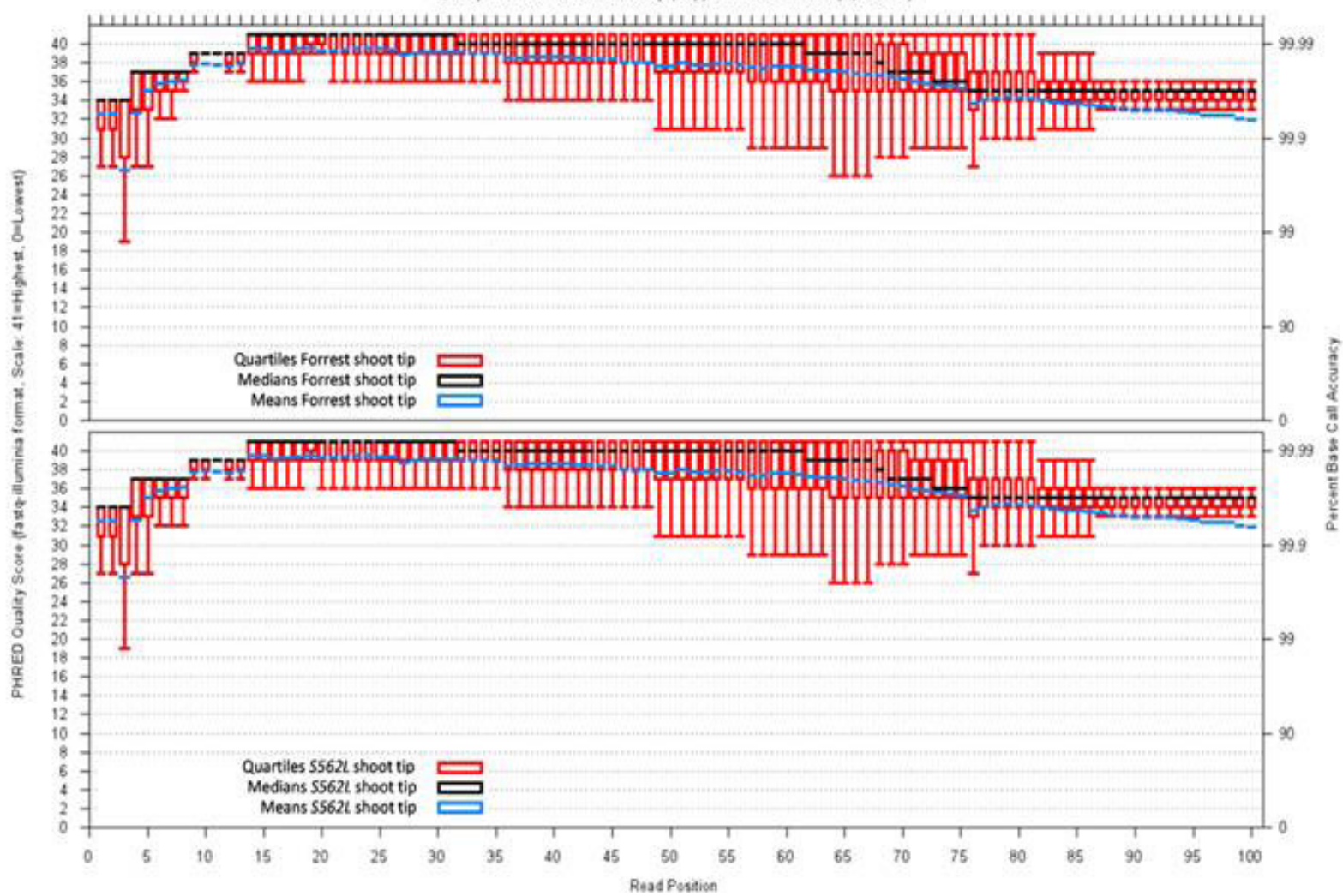

Quality score for Forrest root tip (Top) and S562L root tip (bottom)

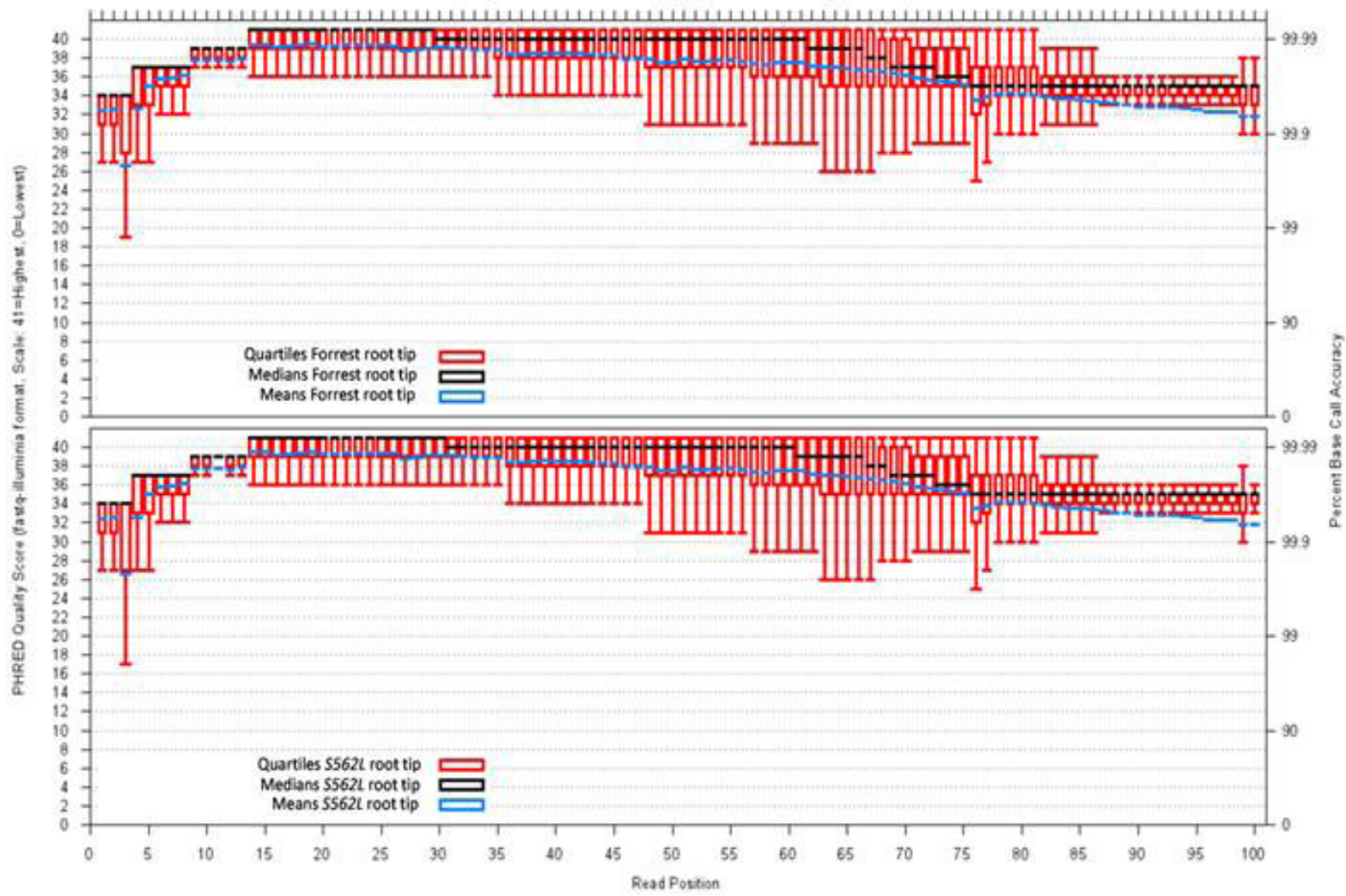

Figure 1. Phred quality scores of RNA sequencing reads. The percentage of base calling accuracy for each base position of the read. The $X$ axis shows read position and the $Y$ axis on the left shows the phred score and on the right shows the percentage of base call accuracy. 
Chalcone and

stilbene synthase

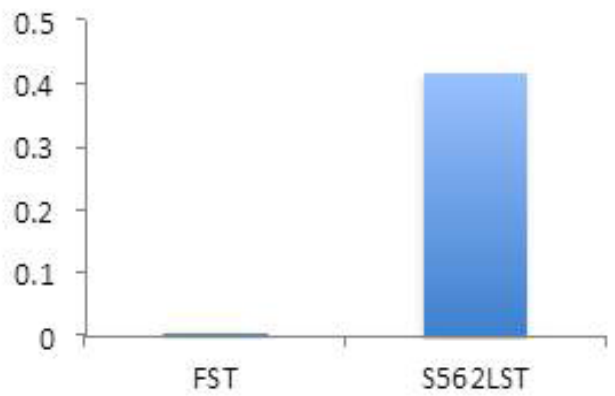

¿̊

U WUSCHEL related

† homeobox 13

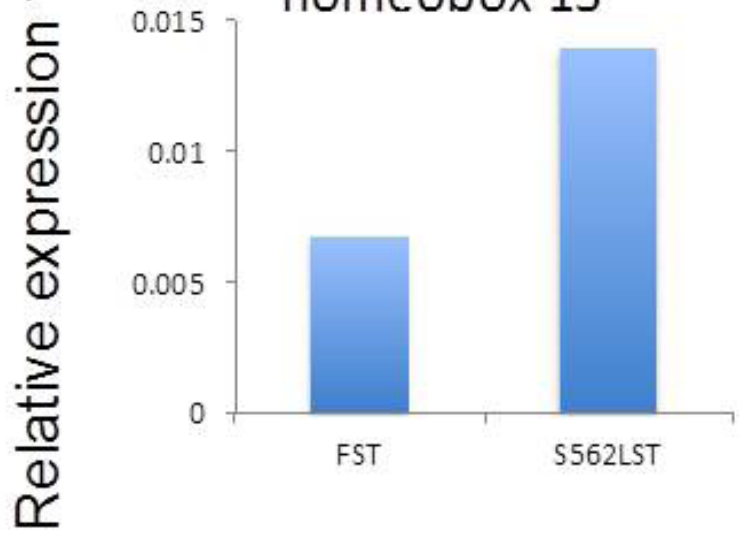

Succinyl-CoA ligase

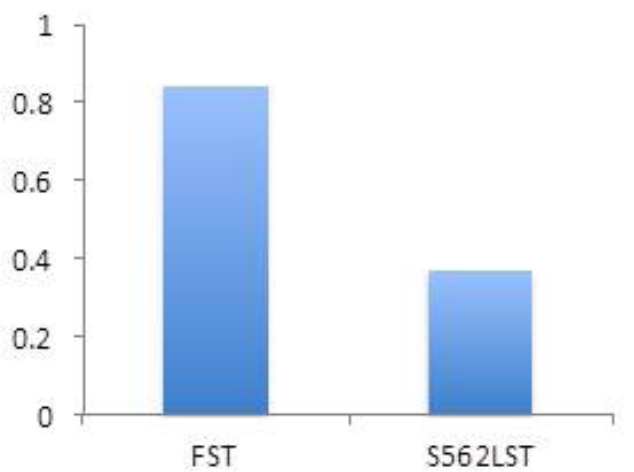

Homogentisate phytyltransferase 1

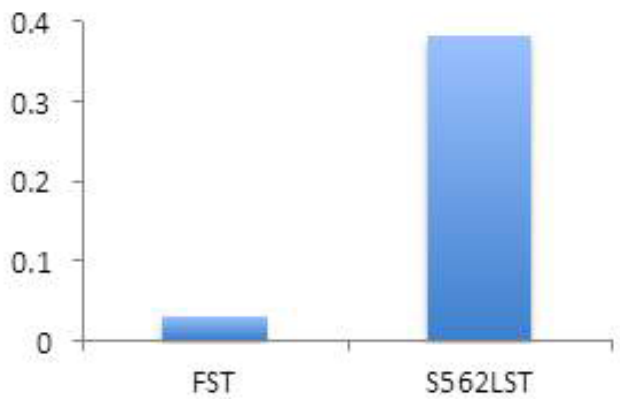

Response regulator 9

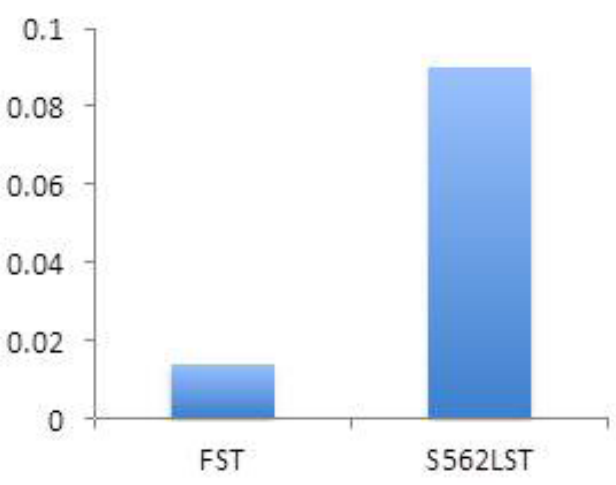

ACC oxidase 1

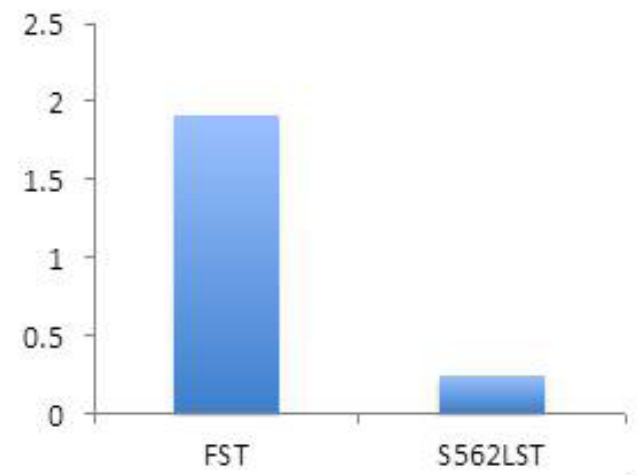

Figure 2. qRT-PCR analysis of six differentially expressed genes (based on RNA-seq) in the shoot samples. This analysis was done in the same shoot samples used for high-throughput RNA sequencing. FST: Forrest shoot tip, S562LST: S562L shoot tip. 
GLN phosphoribosyl pyrophosphate amidotransferase 1

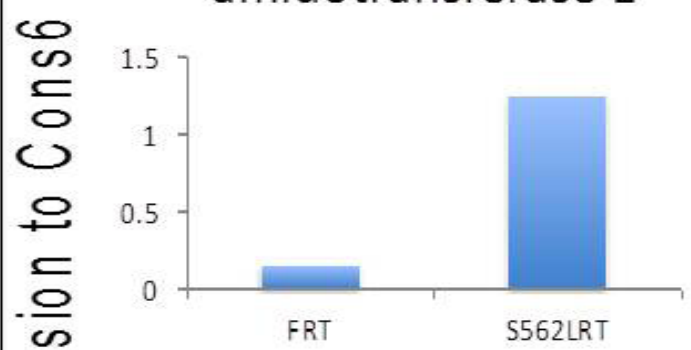

Chalcone and stilbene synthase

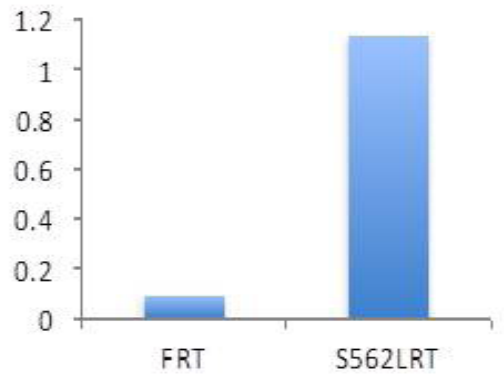

$\mathrm{CCCH}$-type zinc finger family protein

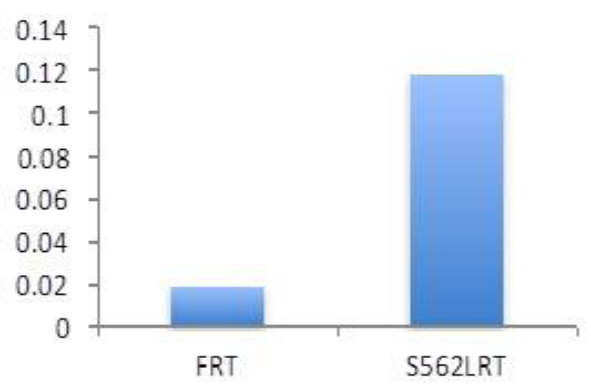

NAC-like

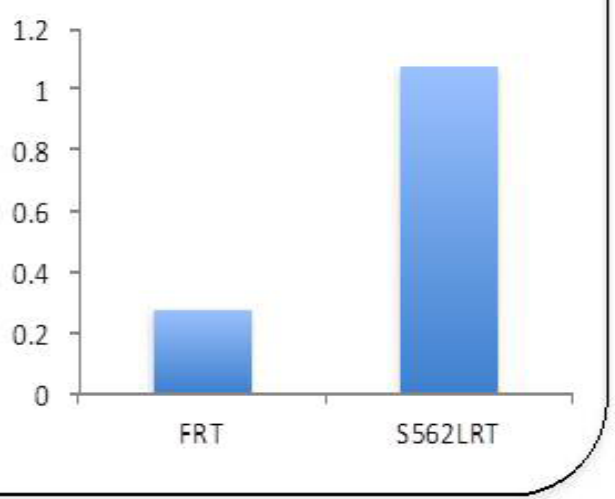

Figure 3. qRT-PCR analysis of four differentially expressed genes (based on RNA-seq) in the root samples. This analysis was done in the same root samples used for high-throughput RNA sequencing. FRT: Forrest root tip, S562LRT: S562L root tip.

Confirming the Expression of Some Differentially-Expressed Genes at the Shoot Tip

From differentially-expressed genes, ten candidate genes (eight had over-expression and two had reduced-expression in the shoot or root tip of S562L) were selected based on homology to Arabidopsis genes that could influence the CLV pathway or were acting in developmental pathways (Table 2). The expression of the selected genes was confirmed by qRT-PCR. qRTPCR was carried out on the exact RNA samples that were used for deep sequencing. The result showed that the expression of all selected genes was consistent with the deep sequencing results (Figures 2 and 3).

\section{Soybean Functional Categories Regulated in the Shoot Tip}

Functional categories of genes that were differentially expressed in the S562L shoot tip compared to the wild type shoot tip were analysed using Mapman (Thimm et al., 2004) and Pageman, an integrated program in Mapman. This analysis, applying the Wilcoxon test with Benjamini-Hochberg correction, revealed 141 functional pathways (bins and sub-bins) to be sta- tistically different from the other pathways $(p<0.05$; Table S3; see additional file). These pathways are distributed into 22 bins out of 37 bins. Categories over-represented in the shoot tip of S562L included photosynthesis, cell wall, secondary metabolism, hormone metabolism, redox regulation, signalling and transport bins and sub-bins. Under-represented functional categories included polyamine metabolism, nucleotide metabolism, RNA, DNA and protein bins and sub-bins.

\section{Soybean Functional Categories Regulated in the Root Tip}

A comparison of the RNA-seq root tip outputs of S562L and its wild type found a total of 71 biological functional pathways to be statistically different from all other Bins $(p<0.05$; Table S4; see additional file). Over-represented categories included photosynthesis, lipid metabolism, amino acid metabolism, secondary metabolism hormone metabolism, redox regulation, nucleotide metabolism, DNA, signalling, development and transport and under-represented functional categories included fermentation, cell wall, biosynthesis, stress, RNA, protein and cell biology. 


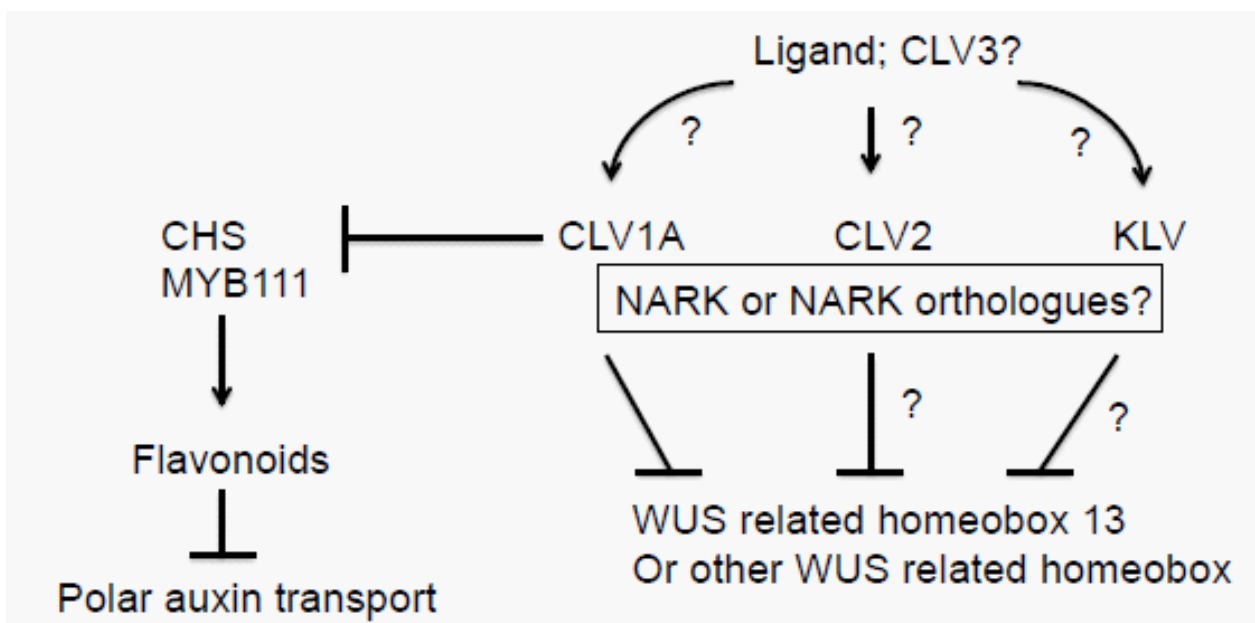

Figure 4. Predicted model of the regulatory network of factors acting in the legume SAM. In the model, it is proposed that GmCLV1A, CLV2 and KLV perceive a ligand probably similar to CLV3 in Arabidopsis and then negatively regulate a WUS-related protein. There is possibility that AON genes such as NARK also interact with GmCLV1A in some aspect of plant development. GmCLV1A also negatively regulates favonoids biosynthesis. Arrows indicate positive regulation and barred lines indicate negative regulation. '?' implies 'unknown'.

Table 2. Expression fold changes and putative annotation of genes selected for qRT-PCR.

\begin{tabular}{lcc}
\hline Gene ID & Putative annotation & Proportion fold change \\
\hline Shoot Samples & Chalcone and stilbene synthase & \\
Glyma08g11620 & Homogentisate phytyltransferase 1 & 39.30 \\
Glyma10g44170 & WUSCHEL related homeobox 13 & 9.73 \\
Glyma06g01940 & Response regulator 9 & 5.38 \\
Glyma04g29250 & Succinyl-CoA ligase & 8.19 \\
Glyma16g33870 & ACC oxidase 1 & -18.38 \\
Glyma05g36310 & & -5.29 \\
Root Samples & GLN phosphoribosyl pyrophosphate amidotransferase 1 & 7.99 \\
Glyma04g00930 & CCCH-type zinc finger family protein & 7.15 \\
Glyma06g05300 & Chalcone and stilbene synthase & 6.91 \\
Glyma08g11620 & NAC-like, activated by AP3/PI & 4.58 \\
Glyma07g35630 & C. & \\
\hline
\end{tabular}

\section{Discussion}

RNA-seq analysis provided a broad view of the gene expression in the S562L shoot and root tip regions compared with the wild type. Our data revealed genes involved in signalling, transcription, metabolism and defense and stress response are over-represented in the S562L shoot and root tip. Moreover, genes that belong to the receptor protein kinase and transcription factor families, which are important in signalling and plant development, were also shown to have higher transcript abundance in the shoot and root tip of S562L compared to the wild type.

WUS encodes a homeodomain transcription factor and is expressed in the organising centre at the SAM (Schoof et al., 2000). WUS regulates the meristem size through cytokinin sig- naling via repression of several type-A Arabidopsis response regulators (ARRs) (ARR5, ARR6, ARR7 and ARR 15) as well as activation of CLV3 transcription by binding to its regulatory region (Leibfried et al., 2005; Yadave et al., 2011 1). Our RNA-seq data and qRT-PCR revealed that Glyma06g01940 (putative orthologue of AT4G35550; WUSCHEL related homeobox 13) was transcribed higher in the $S 562 L$ shoot tip, which is reminiscent of the finding in Arabidopsis where the WUS expression domain expanded in the clv SAM (Schoof et al., 2000). This indicates that GmCLV 1 A of soybean is acting through a similar component as the CLV network in Arabidopsis.

Receptor kinases are key elements in ligand-receptor systems to communicate signals in multicellular organism (i.e., plants) and are involved in diverse pathways in growth and development (Searle et al., 2003; Dievart et al., 2004; Shiu et al., 2004). In 
Table 3. Primer sequences used for $q R T-P C R$.

\begin{tabular}{lll}
\hline Gene ID & Forward primer(5'-3') & Reverse primer(5'-3') \\
\hline Glyma08g11620 & TCCACCCCCATCATCATATC & TTGCGCCTTACGAATCTCTT \\
Glyma10g44170 & TTCACGACACAAAAGGGAAAC & AGCATGAGCTTCAAAACCAA \\
Glyma06g01940 & TCAAACGCTGGTGGTATTATTG & GACAGATGGTGGCATAGACAGA \\
Glyma04g29250 & CTCAGAGAATGTCCCAGCAAG & TTTCAACAAATGTGGCCTCAG \\
Glyma16g33870 & TGACATATGAAGCGGTTTTCC & TCTGAAGGCAGTCAACGAAGT \\
Glyma05g36310 & ACCTTCCAAGAACAATGCCAT & TCCAATGGGGTTATAGAAGGTG \\
Glyma04g00930 & GGTGTACCCGGGTGAAGTTAT & ACCTCCCGAAAACAACAGAGT \\
Glyma06g05300 & AACAACTCCGCCTCGTAGTAAC & ATTTTAACATTCCGCGTTGAGT \\
Glyma07g35630 & CCTCCTGGCTTTAGGTTTCAC & GCAATTCCCAAGGATCAAACT \\
\hline
\end{tabular}

Gene ID is according to the Phytozome database (http://www.phytozome.net).

Arabidopsis thaliana, the CLV family [19], ERECTA family (Torii et al., 1996; Uchida et al., 2013), BAM family (DeYoung et al., 2006; DeYoung and Clark, 2008), RPK2 (Kinoshita et al., 2010), RPK1 (receptor like protein kinase1) and ACR4 (Arabidopsis Crinkly4) (De Smet et al., 2008; 2009) are all receptor kinases and function in regulating cell division and differentiation in shoot and root meristems. LRR RKs, differentially regulated in the S562L shoot tip and root tip, are presented in Table S1 and Table S2 [see additional file]. None of these LRR RKs are paralogues of the above mentioned LRR RKs, indicating that they represent new candidates that function in signalling at the shoot and root tip and may play a similar role - controlling cell division and differentiation - as the above mentioned receptor kinases.

Transcription factors play critical roles in plant development by regulating positively or negatively the expression level of relevant genes. Analysis of differentially expressed genes revealed their presence in the S562L shoot and root tip (Table S1, 2; see additional file).

Transcripts that are related to AP2 (APETALA2) and a group of AP2, ethylene responsive element binding proteins, EREBPs, were also found to be differentially expressed in the shoot and root tip of S562L (Table S1, 2; see additional file). AP2/EREBP transcription factors are expressed in different tissues including: flower, leaves, inflorescence stem and root (Okamuro et al., 1997) and they are involved in several developmental processes that include: seed development, stem cell identity, floral organ identity, plant growth, nodulation and defense response (Agrawal et al., 2011 ; Andriankaja et al., 2007; Aoyama et al., 2012; Jofuku et al., 1994; Krishnaswamy et al., 2011 ; Yant et al., 2010). AP2-related transcripts are under-represented in the shoot while they are over- and under-represented in the root tip of S562L (Table S1, 2; see additional file). This suggests that the defect in GmCLV1 A function, which is involved in plant development of soybean, might associate with over- and under-represented transcripts of this group of transcription factors which function in developmental processes such as stem cell and thus nodal identity.

Some transcripts correspond to the NAC (NAM, ATAF1 / 2 and CUC2) domain containing proteins, are also over-represented in the shoot and root tip of S562L (Table S1, 2). NAC domain containing proteins are another group of transcription factors that are involved in a wide range of biological processes, including embryogenesis, flower development, SAM development, wood formation and shoot branching (Aida et al., 1997; Hu et al., 2010; Mao et al., 2007; Ohtani et al., 201 1; Xie et al., 2000). Interestingly, Glyma02g26480 is a putative orthologue of ATAF1 (AT1G01720) was over-represented in the shoot tip of S562L. ATAF1 is a homologue of the NAM (No Apical Meristem) gene in Petunia (Sover et al., 1996). In Petunia, nam mutants fail to develop a SAM (Sover et al., 1996). This indicates that the over-expression of this gene might be due to impaired $\mathrm{Gm}$ CLV1A function in the S562L mutant. However, it has been shown that ATAF1 is involved in stress responses (Hu et al., 2010; Wang et al., 2009). Furthermore, Glyma 13 g35550, over-represented in the root tip data set, is also an ATAF 1 -like gene.

There are genes highly expressed in the root and shoot tip of $5562 L$ that correspond to those of the WRKY transcription factors family (Table S1, 2; see additional file). WRKY transcription factors act as activators or repressors and control many plant biological processes including germination, senescence, biotic and abiotic responses and development. Moreover, WRKY factors have a key role in the innate immune system of plants (Rushton et al., 2010).

Flavonoids play a pivotal role in plant biology. They protect plants against UV irradiation, attract pollinators and symbionts, and contribute to plant hormone signalling (Dixon and Pasinetti, 2010; Stracke et al., 2007). MYB transcription factors also act in various plant biological processes and impact development, biotic and abiotic stresses and metabolism (Dubos et al., 2010). There is a member of the MYB transcription factors among the differentially regulated genes in the S562L shoot tip, which is involved in favonol biosynthesis. Glyma 16g02570, a putative orthologue of MYB 111 , was over-represented in the 
transcriptome data base of the S562L shoot tip. In Arabidopsis, MYB 111 controls favonol biosynthesis and is mainly active in cotyledons (Stracke et al., 2007). As flavonol accumulation regulates polar auxin transport (Kuhn et al., 2011), it is likely that some phenotypes of S562L, such as increased branching, are the result of flavonol accumulation due to higher expression of Glymal6g02570. Members of this group were also over-represented in the root tip data of S562L. Of interest is Glyma03g341 10, a putative orthologue for AtMYB68. It is specifically expressed in the root and responds to environmental conditions, temperature in particular (Feng et al., 2004). There is a possibility that over-expression of this gene causes a stronger phenotype of S562L under cold conditions; however, AtMYB68 expression is elevated at high temperature (Feng et al., 2004).

Putative orthologues of Arabidopsis chalcone synthase (CHS) including Glyma08g 1 1620, Glyma08g1 1520, Glyma081 1650 and Glyma02g 14450 , were found to have higher expression in the S562L shoot and root tips compared to wild type shoot and root tips. CHS is a key enzyme in flavonoids biosynthesis (Winkel-Shirley, 2001). This suggests a correlation between flavonoid biosynthesis and CLV signalling which may cause developmental outcomes.

Overall, the existence of numerous transcription factors among the differentially expressed genes identified in this study is consistent with recent studies which show a wide range of transcription factors are active in the SAM and RAM of soybean (Haerizadeh et al., 2009; 201 1). Furthermore, over-representation of transcripts for MYB and WRKY transcription factors which are involved in a wide range of plant processes and mainly function in abiotic and biotic stresses, could be explained by SAM and RAM immunity systems, which may be affected by impaired function of GmCLV1A. A recent study demonstrates that CLV3, a main regulator of stem cell homeostasis, can also activate innate immunity (Lee et al., 2011 ). Moreover, Mathesius et al. (2011) by comparison of root tip and differentiated root, highlighted the importance of stress, defense response and flavonoid metabolism in the root apex.

\section{Conclusions and Future Work}

Past studies using the model plant Arabidopsis revealed regulatory pathways in the SAM and RAM that sustain stem cells in both shoot and root meristems and exhibited some similarities between molecules and mechanisms. In legumes, it seems there is a divergence in CLVI function as CLV1 orthologues in legumes, except for GmCLV1 A in soybean, are involved in nodulation control. GmCLVIA (a paralogue of GmNARK, which is a key component in the regulation of nodule formation), acts in shoot architecture, leaf and pod development (Mirzaei et al., 2014; submitted). Investigation of the shoot tip transcriptome of $\mathrm{S} 562 \mathrm{~L}$ indicated that GmCLV1A suppresses the expression of Glyma06g01940 (WUSCHEL related homeobox 13) reminiscent of CLV1 function in Arabidopsis. This finding along with the evidence of the function of LiCLV2, PsCLV2 (Krusell et al., 2011) and LiKLV (Lotus japonicus KLAVIER) (Miyazawa et al., 2010) in the SAM indicates that components similar to Arabidopsis regulatory elements are most likely acting in specialised shoot struc- tures in legumes (Figure 4). Furthermore, it seems that GmCLV1 A negatively controls the flavonoids biosynthesis through the chalcone synthase and the MYB 111 transcription factor. As auxin polar transport is regulated by flavonoids (Kuhn et al., 2011; Falcone et al., 2012), there is a possibility that they also have a function in regulating legume shoot structure.

Further research is required revealing how pathways regulating flavonoids biosynthesis and pathways regulating plant development are connected together in the legume family. Moreover, more studies are required to identify other components (known or unknown in Arabidopsis) regulating the SAM of legumes. As mutations in $L j C L V 2 / P s C L V 2$ and $L j K L V$ lead to hyper-nodulation as well as stem fasciation (Krusell et al., 201 1; Miyazawa et al., 2010), such lines of research may aid in understanding not only the molecular mechanisms underlying SAM regulation in legumes, but also pathways acting in nodulation.

\section{Abbreviations}

SAM: Shoot Apical Meristems

RAM: Root Apical Meristems

CLV: CLAVATA

LRR-RK: Leucine-Rich Repeat Receptor Kinase

AON: Autoregulation Of Nodulation

RPKM: Read Per Kilobase of exon model per Million mapped reads

ARRs: Arabidopsis Response Regulators

RPK 1: Receptor like Protein Kinase 1

ACR4: Arabidopsis Crinkly4

AP2: APETALA2

EREBPs: Ethylene Responsive Element Binding Proteins

KLV: KLAVIER

dNTPs: deoxynucleoside triphosphates

DTT: dithiothreitol

\section{Competing Interest}

The authors declare that they have no competing interests.

\section{Author Contribution}

$S M$ conducted experiments, evaluated results and wrote the manuscript. JB, BJF and PMG contributed to the conception, interpretation and supervision of the research and editing of the manuscript.

\section{Acknowledgements}

We thank the Australian Research Council and The University of Queensland for support through the Centre of Excellence scheme. We also thank A/Prof. Paul Ebert and Dr David Schlipalius at $U Q$ for helping with analysing data using the CLC genomics workbench. Satomi Hayashi, Dr Dugald Reid, and Dr Stephen Kazakoff (all CILR) are thanked for technical discussion. 


\section{References}

Agarwal P, S Kapoor, and AK Tyagi (2011) Transcription factors regulating the progression of monocot and dicot seed development. Bioessays 33: 189-202.

Aida M, T Ishida, H Fukaki, H Fujisawa, and M Tasaka (1997) Genes involved in organ separation in Arabidopsis: an analysis of the cupshaped cotyledon mutant. The Plant Cell Online 9: 841-857.

Andriankaja A, A Boisson-Dernier, L Frances, L Sauviac, A Jauneau, DG Barker, and $F$ de Carvalho-Niebel (2007) AP2-ERF transcription factors mediate nod factor-dependent Mt ENOD1 1 activation in root hairs via a novel cis-regulatory motif. The Plant Cell Online 19: 2866-2885.

Aoyama T, Y Hiwatashi, M Shigyo, R Kofuji, M Kubo, M Ito, and M Hasebe (2012) AP2-type transcription factors determine stem cell identity in the moss Physcomitrella patens. Development 139: 3120 3129.

Clark SE, MP Running, and EM Meyerowitz (1993) CLAVATA1, a regulator of meristem and flower development in Arabidopsis. Development 119: 397-418.

Clark SE, Williams RW, Meyerowitz EM: The CLAVATAl gene encodes a putative receptor kinase that controls shoot and floral meristem size in Arabidopsis. Cell 1997, 89:575-585.

De Smet I, V Vassileva, B De Rybel, MP Levesque, W Grunewald, D Van Damme, G Van Noorden, M Naudts, G Van Isterdael, R De Clercq, et al. (2008) Receptor-like kinase ACR4 restricts formative cell divisions in the Arabidopsis root. Science 322: 594-597.

De Smet I, U Vosz, G Jurgens, and T Beeckman (2009) Receptor-like kinases shape the plant. Nat Cell Biol 1 1: 1166-1173.

DeYoung BJ, KL Bickle, KJ Schrage, P Muskett, K Patel, and SE Clark (2006) The CLAVATA1-related BAM1, BAM2 and BAM3 receptor kinase-like proteins are required for meristem function in Arabidopsis. The Plant Journal 45: 1-16.

DeYoung BJ and SE Clark (2008) BAM receptors regulate stem cell specification and organ development through complex interactions with CLAVATA signaling. Genetics 180: 895-904.

Dievart A and SE Clark (2004) LRR-containing receptors regulating plant development and defense. Development 131: 251-261.

Dixon RA and GM Pasinetti (2010) Flavonoids and isoflavonoids: from plant biology to agriculture and neuroscience. Plant Physiology 154: 453-457.

Dubos C, R Stracke, E Grotewold, B Weisshaar, C Martin, and L Lepiniec (2010) MYB transcription factors in Arabidopsis. Trends in Plant Science 15: 573-581.

Falcone Ferreyra ML, S Rius, and P Casati (2012) Flavonoids: Biosynthesis, Biological functions and Biotechnological applications. Frontiers in Plant Science 2012, 222, 3.

Feng CP, E Andreasson, A Maslak, HP Mock, O Mattsson, and J Mundy (2004) Arabidopsis MYB68 in development and responses to environmental cues. Plant Science 167: 1099-1 107.

Ferguson BJ, A Indrasumunar, S Hayashi, MH Lin, YH Lin, DE Reid, and PM Gresshoff (2010) Molecular analysis of legume nodule development and autoregulation. Journal of Integrative Plant Biology 52: 61-76.

Fletcher JC (2002) Shoot and floral meristem maintenance in Arabidopsis. Annual Review of Plant Biology 53: 45-66.

Gepts P, WD Beavis, EC Brummer, RC Shoemaker, HT Stalker, NF Weeden, and ND Young (2005) Legumes as a model plant family. Genomics for food and feed report of the cross-legume advances through genomics conference. Plant Physiology 137: 1228-1 235.

Graham PH and CP Vance (2003) Legumes: Importance and constraints to greater use. Plant Physiology 131: 872-877.
Haerizadeh F, MB Singh, and PL Bhalla (2011) Transcriptome profiling of soybean root tips. Functional Plant Biology 38: 451-461.

Haerizadeh F, CE Wong, MB Singh, and PL Bhalla (2009) Genomewide analysis of gene expression in soybean shoot apical meristem. Plant Mol Biol 69: 71 1-727.

Hayashi S, DE Reid, MT Lorenc, J Stiller, D Edwards, PM Gresshoff, and BJ Ferguson (2012) Transient nod factor-dependent gene expression in the nodulation-competent zone of soybean (Glycine $\max$ [L.] Merr.) roots. Plant Biotechnology Journal 10: 995-1010.

Hu R, G Qi, Y Kong, D Kong, Q Gao, and G Zhou (2010) Comprehensive analysis of NAC domain transcription factor gene family in Populus trichocarpa. BMC Plant Biology 2010, 10: 145.

Jofuku KD, BG den Boer, M Van Montagu, and JK Okamuro (1994) Control of Arabidopsis flower and seed development by the homeotic gene APETALA2. The Plant Cell Online 6: 1211-1225.

Kal AJ, AJ van Zonneveld, V Benes, M Van den Berg, MG Koerkamp, $K$ Albermann, N Strack, JM Ruijter, A Richter, B Dujon B, et al. (1999) Dynamics of gene expression revealed by comparison of serial analysis of gene expression transcript profiles from yeast grown on two different carbon sources. Molecular Biology of the Cell 10: 1859-1872.

Kinoshita A, S Betsuyaku, Y Osakabe, S Mizuno, S Nagawa, Y Stahl, R Simon, K Yamaguchi-Shinozaki, H Fukuda, and S Sawa (2010) RPK2 is an essential receptor-like kinase that transmits the CLV3 signal in Arabidopsis. Development 137: 3911-3920.

Krishnaswamy S, S Verma, M Rahman, and NV Kav (2011) Functional characterization of four APETALA2-family genes (RAP2.6, RAP2.6L, DREB 19 and DREB26) in Arabidopsis. Plant Mol Biol 75: 107-1 27.

Krusell L, N Sato, I Fukuhara, BEV Koch, C Grossmann, S Okamoto, E Oka-Kira, Y Otsubo, G Aubert, T Nakagawa, et al. (2011) The Clavata 2 genes of pea and Lotus japonicus affect autoregulation of nodulation. The Plant Journal 65: 861-871.

Kuhn BM, M Geisler, L Bigler, and C Ringli (2011) Flavonols accumulate asymmetrically and affect auxin transport in Arabidopsis. Plant Physiology 156: 585-595.

Lee H, OK Chah, and J Sheen (2011) Stem-cell-triggered immunity through CLV3p-FLS2 signalling. Nature 473: 376-U559.

Leibfried A, JPC To, W Busch, S Stehling, A Kehle, M Demar, JJ Kieber, and JU Lohmann (2005) WUSCHEL controls meristem function by direct regulation of cytokinin-inducible response regulators. Nature 438: 1172-1175.

Libault $M$, A Farmer, T Joshi, K Takahashi, RJ Langley, LD Franklin, J He, D Xu, G May, and G Stacey (2010) An integrated transcriptome atlas of the crop model Glycine max, and its use in comparative analyses in plants. The Plant Journal 63: 86-99.

Libault $M$, S Thibivilliers, DD Bilgin, O Radwan, M Benitez, SJ Clough, and $G$ Stacey (2008) Identification of four soybean reference genes for gene expression normalization. Plant Genome 1: 44-54.

Mao C, W Ding, Y Wu, J Yu, X He, H Shou, and P Wu (2007) Overexpression of a NAC-domain protein promotes shoot branching in rice. New Phytologist 176: 288-298.

Mathesius U, MA Djordjevic, M Oakes, N Goffard, F Haerizadeh, GF Weiller, MB Singh, and PL Bhalla (2011) Comparative proteomic profiles of the soybean (Glycine $\max$ ) root apex and differentiated root zone. Proteomics 11: 1707-1719.

Miyazawa H, E Oka-Kira, N Sato, H Takahashi, GJ Wu, S Sato, M Hayashi, S Betsuyaku, M Nakazono, S Tabata, et al. (2010) The receptor-like kinase KLAVIER mediates systemic regulation of nodulation and non-symbiotic shoot development in Lotus japonicus. Development 137: 4317-4325.

Ohtani M, N Nishikubo, B Xu, M Yamaguchi, N Mitsuda, N Goué, F Shi, M Ohme-Takagi, and T Demura (2011) A NAC domain protein fam- 
ily contributing to the regulation of wood formation in poplar. The Plant Journal 67: 499-512.

Okamuro JK, B Caster, R Villarroel, M VanMontagu, and KD Jofuku (1997) The AP2 domain of APETALA2 defines a large new family of DNA binding proteins in Arabidopsis. Proceedings of the $\mathrm{Na}$ tional Academy of Sciences of the United States of America 94: 7076-7081.

Ozsolak F, AR Platt, DR Jones, JG Reifenberger, LE Sass, P Mclnerney, JF Thompson, J Bowers, M Jarosz, and PM Milos (2009) Direct RNA sequencing. Nature 461: 814-873.

Ramakers C, JM Ruijter, RHL Deprez, and AFM Moorman (2003) Assumption-free analysis of quantitative real-time polymerase chain reaction (PCR) data. Neuroscience Letters 339: 62-66.

Reid DE, S Hayashi, M Lorenc, J Stiller, D Edwards, PM Gresshoff, and BJ Ferguson (2012) Identification of systemic responses in soybean nodulation by xylem sap feeding and complete transcriptome sequencing reveal a novel component of the autoregulation pathway. Plant Biotechnology Journal 10: 680-689.

Rushton PJ, IE Somssich, P Ringler, and QJ Shen (2010) WRKY transcription factors. Trends in Plant Science 15: 247-258.

Schoof H, M Lenhard, A Haecker, KFX Mayer, G Jürgens, and T Laux (2000) The stem cell population of Arabidopsis shoot meristems is maintained by a regulatory loop between the CLAVATA and WUSCHEL genes. Cell 100: 635-644.

Searle IR, AE Men, TS Laniya, DM Buzas, I lturbe-Ormaetxe, BJ Carroll, and PM Gresshoff (2003) Long-distance signaling in nodulation directed by a CLAVATA 1-like receptor kinase. Science 299: 109-1 12.

Sharma VK, C Carles, and JC Fletcher (2003) Maintenance of stem cell populations in plants. Proceedings of the National Academy of Sciences of the United States of America 100: 11823-11829.

Shiu SH, WM Karlowski, R Pan, YH Tzeng, KFX Mayer, and WH Li (2004) Comparative analysis of the receptor-like kinase family in Arabidopsis and rice. Plant Cell 16: 1220-1234.

Sover E, A Van Houwelingen, D Kloos, J Mol, and R Koes (1996) The no apical meristem gene of Petunia is required for pattern formation in embryos and flowers and is expressed at meristem and primordia boundaries. Cell 85: 159-170.

Stahl Y and R Simon (2010) Plant primary meristems: shared functions and regulatory mechanisms. Current Opinion in Plant Biology 10:
53-58.

Stracke R, H Ishihara, GHA Barsch, F Mehrtens, K Niehaus, and B Weisshaar (2007) Differential regulation of closely related R2R3-MYB transcription factors controls flavonol accumulation in different parts of the Arabidopsis thaliana seedling. Plant Journal 50: 660-677.

Thimm O, O Bläsing, Y Gibon, A Nagel, S Meyer, P Krüger, J Selbig, LA Müller, SY Rhee, and M Stitt (2004) Mapman: a user-driven tool to display genomics data sets onto diagrams of metabolic pathways and other biological processes. The Plant Journal 37: 914-939.

Torii KU, N Mitsukawa, T Oosumi, Y Matsuura, P Yokoyama, RF Whittier, and $Y$ Komeda (1996) The Arabidopsis ERECTA gene encodes a putative receptor protein kinase with extracellular leucine-rich repeats. The Plant Cell 8: 735-746.

Traas J and O Hamant (2009) From genes to shape: Understanding the control of morphogenesis at the shoot meristem in higher plants using systems biology. Comptes Rendus Biologies 332: 974-985.

Uchida N, M Shimada, and M Tasaka (2013) ERECTA-family receptor kinases regulate stem-cell homeostasis via buffering its cytokinin responsiveness in the shoot apical meristem. Plant and Cell Physiology 54 (3): 343-351.

Wang Xe, BMVS Basnayake, H Zhang, G Li, W Li, N Virk, T Mengiste, and F Song (2009) The Arabidopsis ATAFl, a NAC transcription factor, is a negative regulator of defense responses against necrotrophic fungal and bacterial pathogens. Molecular Plant-Microbe Interactions 22: 1227-1238.

Winkel-Shirley B (2001) Flavonoid Biosynthesis. A Colorful Model for Genetics, Biochemistry, Cell Biology, and Biotechnology. Plant Physiology 126: 485-493.

Xie Q, G Frugis, D Colgan, and NH Chua (2000) Arabidopsis NAC1 transduces auxin signal downstream of TIR 1 to promote lateral root development. Genes \& Development 14: 3024-3036.

Yadar RK, M Perales, J Gruel, T Girke, H Jönsson, GV Reddy (2011) WUSCHEL protein movement mediates stem cell homeostasis in the Arabidopsis shoot apex. Genes \& Development 25: 2025-2030.

Yant L, J Mathieu, TT Dinh, F Ott, C Lanz, H Wollmann, X Chen, and $M$ Schmid (2010) Orchestration of the floral transition and floral development in Arabidopsis by the bifunctional transcription factor APETALA2. The Plant Cell Online 22: 2156-2170. 


\section{Mirzaei et al., 2014 - Supplementary Data}

Table S1. A representative list of the genes that were differentially transcribed in the shoot tip of S562L compared with those of the wild type. Light green and light pink represent the most up-regulated and down-regulated gene in each category respectively. Grey shows genes that were differentially-expressed in both the shoot and root tip.

\begin{tabular}{|c|c|c|c|}
\hline Gene Name & Proportion fold change & P-value & Putative annotation \\
\hline \multicolumn{4}{|l|}{ Protein kinase } \\
\hline Glyma13g09870 & 6.95 & 0.02 & Protein kinase superfamily protein \\
\hline Glyma13g09810 & 6.08 & 0.015 & Protein kinase superfamily protein \\
\hline Glymal lg00320 & 4.55 & 0.041 & Leucine-rich repeat (LRR) family protein \\
\hline Glyma20g27480 & 3.76 & 0.0009794 & Cysteine-rich RLK (RECEPTOR-like protein kinase) 29 \\
\hline \multicolumn{4}{|l|}{ Transcription factor } \\
\hline Glyma05g31800 & 271.42 & 0.004925 & WRKY DNA-binding protein 51 \\
\hline Glyma08g15050 & 41.48 & 0.002085 & WRKY DNA-binding protein 51 \\
\hline Glyma15g00570 & 9.28 & 0.0004699 & WRKY DNA-binding protein 40 \\
\hline Glyma18g44030 & 9.02 & 0.029 & WRKY DNA-binding protein 33 \\
\hline Glyma05g36970 & 5.07 & 0.016 & WRKY family transcription factor \\
\hline Glyma09g00820 & 3.66 & 0.005466 & WRKY family transcription factor \\
\hline Glyma09g41050 & 3.45 & 0.001657 & WRKY DNA-binding protein 70 \\
\hline Glyma08g23380 & 3.35 & 0.041 & WRKY DNA-binding protein 40 \\
\hline Glyma19g43420 & 4.11 & 0.049 & bZIP transcription factor family protein \\
\hline Glyma03g40730 & 3.14 & 0.039 & bZIP transcription factor family protein \\
\hline Glymal lg11790 & -2.08 & 0.032 & Basic-leucine zipper (bZIP) transcription factor family protein \\
\hline Glyma05g35050 & 19.91 & 0.043 & myb domain protein 116 \\
\hline Glyma10g00930 & 18.05 & 0.014 & myb domain protein 15 \\
\hline Glyma16g02570 & 8.04 & 0.00002565 & myb domain protein 111 \\
\hline Glyma10g32410 & 7.53 & 0.003432 & myb domain protein 15 \\
\hline Glyma02g00820 & 5.33 & 0.025 & myb domain protein 15 \\
\hline Glyma20g35180 & 3.08 & 0.01 & myb domain protein 15 \\
\hline Glymal6g04740 & 6.30 & 0.038 & NAC domain containing protein 47 \\
\hline Glyma02g26480 & 2.10 & 0.027 & $\begin{array}{l}\text { NAC (No Apical Meristem) domain transcriptional regulator } \\
\text { superfamily protein }\end{array}$ \\
\hline Glyma08g 47240 & -13.65 & 0.029 & AP2/B3-like transcriptional factor family protein \\
\hline Glyma18g38490 & -4.65 & 0.033 & AP2/B3-like transcriptional factor family protein \\
\hline Glyma18g43750 & -2.28 & 0.022 & Integrase-type DNA-binding superfamily protein \\
\hline Glyma13g31010 & -2.05 & 0.0002355 & ERF domain protein 12 \\
\hline Glyma12g12600 & 5.20 & 0.018 & RING membrane-anchor 1 \\
\hline
\end{tabular}


Table S1. Continued.

\begin{tabular}{|c|c|c|c|}
\hline \multicolumn{4}{|l|}{ Protein binding } \\
\hline Glymal4g07410 & 73.64 & 0.007283 & $\begin{array}{l}\text { Calcium-dependent lipid-binding (CaLB domain) family } \\
\text { protein }\end{array}$ \\
\hline Glyma06g44870 & 30.02 & 0.019 & Ankyrin repeat family protein \\
\hline Glyma02g41540 & 22.40 & 0.044 & $\begin{array}{l}\text { Calcium-dependent lipid-binding (CaLB domain) family } \\
\text { protein }\end{array}$ \\
\hline Glyma03gl6600 & 6.20 & 0.0008464 & Glutathione S-transferase TAU 8 \\
\hline Glymal lg00320 & 4.55 & 0.041 & Leucine-rich repeat (LRR) family protein \\
\hline Glymal6g25080 & 3.68 & 0.037 & Disease resistance protein (TIR-NBS-LRR class), putative \\
\hline Glyma08g08360 & 3.24 & 0.045 & Polygalacturonase inhibiting protein 1 \\
\hline Glyma10g33650 & 3.13 & 0.0008941 & Glutathione S-transferase TAU 15 \\
\hline Glyma01g26220 & 2.66 & 0.0000691 & Glutathione S-transferase TAU 8 \\
\hline Glyma15g40190 & 2.33 & 0.029 & Glutathione S-transferase TAU 19 \\
\hline Glyma06g40710 & 2.22 & 0.047 & Disease resistance protein (TIR-NBS-LRR class), putative \\
\hline Glymal lg33760 & 2.18 & 0.043 & $\begin{array}{l}\text { Calcium-dependent lipid-binding (CaLB domain) family } \\
\text { protein }\end{array}$ \\
\hline Glyma15g03160 & -2.06 & 0.035 & Alfin-like 5 \\
\hline Glyma08g44960 & -3.39 & 0.006228 & Proteasome activating protein 200 \\
\hline Glyma07g04820 & -3.75 & 0.002134 & Chaperone DnaJ-domain superfamily protein \\
\hline \multicolumn{4}{|l|}{$\begin{array}{l}\text { Defense and stress } \\
\text { response }\end{array}$} \\
\hline Glyma09g04520 & 46.20 & $9.26 \mathrm{E}-09$ & Pathogenesis-related protein Bet $v \mid$ family \\
\hline Glyma07g37280 & 33.05 & 0.033 & MLP-like protein 423 \\
\hline Glyma15g15600 & 28.99 & 0.006306 & Pathogenesis-related protein Bet $v$ I family \\
\hline Glyma15g15590 & 15.76 & $3.558 \mathrm{E}-10$ & MLP-like protein 423 \\
\hline Glyma17g03340 & 10.33 & $3.268 \mathrm{E}-11$ & MLP-like protein 423 \\
\hline Glyma07g37270 & 8.05 & $1.355 \mathrm{E}-09$ & MLP-like protein 423 \\
\hline Glyma09g04510 & 4.41 & $4.124 \mathrm{E}-10$ & MLP-like protein 423 \\
\hline Glyma07g37240 & 4.08 & 0 & MLP-like protein 423 \\
\hline Glyma17g03350 & 3.87 & 0.000003783 & MLP-like protein 423 \\
\hline Glyma03g41390 & 6.36 & 0.006478 & Senescence-associated gene 21 \\
\hline Glyma20g23090 & 3.86 & 0.00249 & Adenine nucleotide al pha hydrolases-like superfamily protein \\
\hline Glyma10g02210 & 3.01 & 0.006941 & Senescence-associated gene 21 \\
\hline Glyma04g01130 & -2.36 & 0.000005269 & Cold-regulated 47 \\
\hline
\end{tabular}


Table S1. Continued.

\begin{tabular}{|c|c|c|c|}
\hline \multicolumn{4}{|l|}{ Catalytic activity } \\
\hline Glyma 1 lg31310 & 7.52 & 0.019 & $\begin{array}{l}\text { AMP-dependent synthetase and ligase family } \\
\text { protein }\end{array}$ \\
\hline Glyma09g 40580 & 7.20 & 0.034 & $\begin{array}{l}\text { NAD(P)-binding Rossmann-fold superfamily } \\
\text { protein }\end{array}$ \\
\hline Glyma08g37670 & 6.66 & 0.013 & Deoxyxylulose-5-phosphate synthase \\
\hline Glyma0 1 g44270 & 6.39 & 0.002263 & 4-coumarate:CoA ligase 3 \\
\hline Glyma04g 11250 & 5.96 & 0.047 & $\begin{array}{l}\text { Haloacid dehalogenase-like hydrolase (HAD) } \\
\text { superfamily protein }\end{array}$ \\
\hline Glyma0 $1 \mathrm{~g} 43460$ & 5.38 & 0.033 & Highly ABA-induced PP $2 \mathrm{C}$ gene 3 \\
\hline Glyma04g 13880 & 4.97 & 0.004299 & $\begin{array}{l}\text { Haloacid dehalogenase-like hydrolase (HAD) } \\
\text { superfamily protein }\end{array}$ \\
\hline Glyma 18g45260 & 4.29 & 0.00007771 & $\begin{array}{l}\text { NAD(P)-binding Rossmann-fold superfamily } \\
\text { protein }\end{array}$ \\
\hline Glyma06g05280 & 3.25 & 0.013 & Branched-chain amino acid transaminase 2 \\
\hline Glyma03g19810 & 2.81 & 0.032 & $\begin{array}{l}\text { Haloacid dehalogenase-like hydrolase (HAD) } \\
\text { superfamily protein }\end{array}$ \\
\hline Glyma08g42070 & 2.23 & 0.029 & $\begin{array}{l}\text { ATP-dependent caseinolytic (Clp) } \\
\text { protease/crotonase family protein }\end{array}$ \\
\hline Glyma 13g44950 & 2.22 & 0.049 & 4-coumarate:CoA ligase 2 \\
\hline Glyma07g36770 & -2.95 & 0.039 & Enoyl-CoA hydratase/isomerase A \\
\hline
\end{tabular}


Table S2. A representative list of genes that were differentially transcribed in the root tip of S562L compared with that of the wild type. Light green and light pink represent the most up-regulated and down-regulated gene in each category respectively. Grey indicates genes that were differentially-expressed in both the shoot and root tip.

\section{Proportions}

Gene Name fold change P-value Putative annotation

\section{Receptor kinase \&}

signalling

\begin{tabular}{lccl}
\hline Glyma 20g23890 & 7.67 & 0.00000151 & ACT-like protein tyrosine kinase family protein \\
\hline Glyma08g23340 & 4.64 & 0.018 & CBL-interacting protein kinase 5 \\
Glyma09g33650 & 4.57 & 0 & Phosphoenolpyruvate carboxykinase 1 \\
Glyma08g25600 & 4.41 & 0.023 & Leucine-rich repeat transmembrane protein kinase \\
Glyma02g46670 & 3.24 & 0.021 & Protein kinase superfamily protein \\
Glyma01g02330 & 3.04 & 0.0000316 & Phosphoenolpyruvate carboxykinase 1 \\
Glyma13g38170 & 2.93 & 0.022 & Receptor-like protein kinase-related family protein \\
Glyma17g05660 & 2.69 & 0.037 & Protein kinase superfamily protein \\
Glyma09g41340 & 2.64 & 0.0005498 & SOS3-interacting protein 1 \\
Glyma01g37100 & 2.45 & 0.05 & Calcium-dependent protein kinase 28 \\
Glyma12g07770 & 2.31 & 0.025 & Mitogen-activated protein kinase 3 \\
Glyma02g02790 & 2.17 & 0.004924 & Disease resistance protein (TIR-NBS-LRR class) family \\
Glyma16g06940 & 2.07 & 0.044 & protein
\end{tabular}

\begin{tabular}{lccl} 
Glyma10g30710 & -2.15 & 0.003837 & Leucine-rich receptor-like protein kinase family protein \\
Glyma06g06550 & -2.23 & 0.013 & CBL-interacting protein kinase 25 \\
\hline Glyma11g00320 & 2.48 & 0.046 & Leucine-rich repeat (LRR) family protein \\
\hline Glyma08g04390 & -2.12 & 0.00277 & Leucine-rich repeat (LRR) family protein \\
\hline Glyma15g26790 & -2.72 & 0.0002545 & polygalacturonase inhibiting protein 1
\end{tabular}


Table S2. Continued.

Transcription factor

\begin{tabular}{|c|c|c|c|}
\hline Glyma19g40470 & 6.61 & 0.028 & WRKY DNA-binding protein 35 \\
\hline Glyma01g31920 & 6.40 & 0.012 & WRKY DNA-binding protein 33 \\
\hline Glyma01g43420 & 6.11 & 0.00856 & WRKY family transcription factor \\
\hline Glyma08g02580 & 5.14 & 0.004004 & WRKY family transcription factor \\
\hline Glyma03g05220 & 4.90 & 0.007609 & WRKY DNA-binding protein 33 \\
\hline Glyma05g36970 & 3.37 & 0.009669 & WRKY family transcription factor \\
\hline Glyma15g00570 & 3.33 & 0.002048 & WRKY DNA-binding protein 40 \\
\hline Glyma17g15480 & 2.96 & 0.023 & Ethylene responsive element binding factor 1 \\
\hline Glyma10g34760 & 2.65 & 0.036 & AP2/B3 transcription factor family protein \\
\hline Glyma17g15460 & 2.07 & 0.007356 & Ethylene responsive element binding factor 5 \\
\hline Glyma 14g09320 & 2.06 & 0.032 & Related to AP2 1 \\
\hline Glyma15g16260 & -2.26 & 0.025 & Ethylene-responsive element binding protein \\
\hline Glyma17g33060 & -2.89 & 0.001162 & Integrase-type DNA-binding superfamily protein \\
\hline Glyma19g27790 & -2.89 & 0.0004498 & Integrase-type DNA-binding superfamily protein \\
\hline Glyma03g26450 & -4.71 & 0.02 & Ethylene-responsive element binding factor 13 \\
\hline Glyma19g43420 & 5.27 & 0.0000127 & bZIP transcription factor family protein \\
\hline Glyma03g40730 & 2.46 & 0.002065 & bZIP transcription factor family protein \\
\hline Glyma06g38410 & 8.29 & 0.038 & $\begin{array}{l}\text { NAC (No Apical Meristem) domain transcriptional regulator } \\
\text { superfamily protein }\end{array}$ \\
\hline Glyma07g35630 & 4.58 & 0.00009966 & NAC-like, activated by AP3/PI \\
\hline Glyma01g06150 & 4.20 & 0.024 & NAC-like, activated by AP3/PI \\
\hline Glyma16g04740 & 4.06 & 0.004638 & NAC domain containing protein 47 \\
\hline Glyma13g35550 & 3.87 & 0.0002846 & NAC domain containing protein 3 \\
\hline Glyma17g23740 & 3.42 & 0.044 & NAC domain containing protein 83 \\
\hline Glyma03g34110 & 7.83 & 0.045 & myb domain protein 68 \\
\hline Glyma09g03690 & 5.65 & 0.022 & myb domain protein 78 \\
\hline Glyma02g00820 & 3.45 & 0.02 & myb domain protein 15 \\
\hline Glyma09g37340 & -2.27 & 0.009459 & myb domain protein 30 \\
\hline Glyma06g05300 & 7.16 & 0.009363 & $\mathrm{CCCH}$-type zinc finger family protein \\
\hline Glyma04g05290 & 6.90 & 0.0000799 & $\mathrm{CCCH}$-type zinc finger family protein \\
\hline Glyma12g12600 & 3.11 & $1.516 \mathrm{E}-07$ & RING membrane-anchor 1 \\
\hline Glyma10g29750 & 3.09 & 0.004816 & RING/U-box superfamily protein \\
\hline Glyma03g37740 & 3.07 & 0.039 & RING/FYVE/PHD zinc finger superfamily protein \\
\hline Glyma05g36110 & 3.00 & 0.039 & $\mathrm{CCCH}$-type zinc finger family protein \\
\hline Glyma08g03540 & 2.97 & 0.036 & $\mathrm{CCCH}$-type zinc finger family protein \\
\hline Glyma1 1 g36040 & 2.39 & 0.03 & RING-H2 finger $\mathrm{A} 2 \mathrm{~A}$ \\
\hline Glyma07g24480 & 8.51 & 0.007142 & $\begin{array}{l}\text { GDP dissociation inhibitor family protein / Rab GTPase } \\
\text { activator family protein }\end{array}$ \\
\hline Glyma01g39260 & 3.29 & 0.008994 & Heat shock factor 4 \\
\hline Glyma20g32050 & -2.02 & 0.00006938 & GATA transcription factor 9 \\
\hline Glyma02g06560 & 5.44 & 0.032 & Homeobox protein 40 \\
\hline
\end{tabular}


Table S2. Continued.

\begin{tabular}{|c|c|c|}
\hline \multicolumn{3}{|l|}{ Protein binding } \\
\hline Glyma 10g43670 & 9.06 & 0.034 F-box family protein \\
\hline Glyma $16 g 32230$ & 7.46 & 0.028 Phloem protein $2-\mathrm{A} 13$ \\
\hline Glyma02g04420 & 4.95 & 0.028 Octicosapeptide/Phox/Bem 1 p family protein \\
\hline Glyma06g 17910 & 4.56 & 0.000001083 SNF1 -related protein kinase regulatory subunit gamma 1 \\
\hline Glyma $13 g 44260$ & 4.03 & 0.019 Cystathionine beta-synthase (CBS) protein \\
\hline Glyma $11 \mathrm{~g} 33760$ & 3.33 & 0.0002613 Calcium-dependent lipid-binding (CaLB domain) family protein \\
\hline Glyma01g03150 & 3.29 & 0.01 Octicosapeptide/Phox/Bem 1 p family protein \\
\hline Glyma05g 28820 & 2.95 & 0.04 Galactose oxidase/kelch repeat superfamily protein \\
\hline Glyma01g42420 & 2.57 & 0.031 Phospholipase D beta 1 \\
\hline Glyma $13 g 09290$ & 2.53 & 0.008898 RNI-like superfamily protein \\
\hline Glyma08g10890 & 2.38 & 0.018 Galactose oxidase/kelch repeat superfamily protein \\
\hline Glyma15g01610 & 2.38 & 0.002209 Galactose oxidase/kelch repeat superfamily protein \\
\hline Glyma08g 23540 & 2.26 & 0.001665 Chaperone DnaJ-domain superfamily protein \\
\hline Glyma 10g33650 & 2.17 & 0.00002115 Glutathione S-transferase TAU 15 \\
\hline Glyma 18g01140 & 2.15 & 0.008673 Galactose oxidase/kelch repeat superfamily protein \\
\hline Glyma04g37140 & 2.04 & 0.033 SNF1 -related protein kinase regulatory subunit gamma 1 \\
\hline Glyma08g04390 & -2.12 & 0.00277 Leucine-rich repeat (LRR) family protein \\
\hline Glyma 19g24640 & -2.39 & 0.011 Galactose oxidase/kelch repeat superfamily protein \\
\hline Glyma09g15600 & -2.39 & $0.05 \mathrm{CCCH}$-type zinc finger protein with $A R M$ repeat domain \\
\hline Glyma $16 g 06690$ & -2.81 & 0.002079 Galactose oxidase/kelch repeat superfamily protein \\
\hline Glyma08g44960 & -2.82 & 0.0002941 Proteasome activating protein 200 \\
\hline \multicolumn{3}{|l|}{$\begin{array}{l}\text { Defense and } \\
\text { stress response }\end{array}$} \\
\hline Glyma02g03680 & 7.10 & $0.00001028 \mathrm{MLP}$-like protein 423 \\
\hline Glyma $15 \mathrm{~g} 15590$ & 5.84 & 0.021 MLP-like protein 423 \\
\hline Glyma07g37280 & 5.28 & 0.00628 MLP-like protein 423 \\
\hline Glyma 17g03330 & 4.55 & 0.026 MLP-like protein 423 \\
\hline Glyma $20 \mathrm{~g} 23090$ & 2.34 & 0.02 Adenine nucleotide alpha hydrolases-like superfamily protein \\
\hline Glyma06g 16810 & 2.23 & 0.00000118 Scorpion toxin-like knottin superfamily protein \\
\hline Glyma 15g 13870 & 2.04 & 0.019 \\
\hline \multicolumn{3}{|l|}{ Catalytic activity } \\
\hline Glyma06g45950 & 31.05 & 0.00003716 Isocitrate lyase \\
\hline Glyma06g05280 & 4.69 & 1.221E-14 Branched-chain amino acid transaminase 2 \\
\hline Glyma04g05190 & 4.34 & $1.416 \mathrm{E}-08$ Branched-chain amino acid transaminase 2 \\
\hline Glyma03g40720 & 3.05 & 0.004779 GDP-D-mannose $3 \backslash$ ',5 5 '-epimerase \\
\hline Glyma06g41520 & 3.03 & 0.017 NAD(P)-binding Rossmann-fold superfamily protein \\
\hline Glyma20g28320 & 2.90 & 4.441 E-16 Haloacid dehalogenase-like hydrolase (HAD) superfamily protein \\
\hline Glyma $13 g 01420$ & 2.89 & 0.04 Trehalose phosphatase/synthase 11 \\
\hline GlymaO6g 19590 & 2.70 & 0.018 Trehalose-phosphatase/synthase 9 \\
\hline Glyma 18g 12660 & 2.41 & 0.009343 Rhamnose biosynthesis 1 \\
\hline Glyma 11 g3 1310 & 2.35 & 0.003131 AMP-dependent synthetase and ligase family protein \\
\hline Glyma03g19810 & 2.11 & 0.002617 Haloacid dehalogenase-like hydrolase (HAD) superfamily protein \\
\hline Glyma09g05590 & -2.01 & 0.009678 Haloacid dehalogenase-like hydrolase (HAD) superfamily protein \\
\hline Glyma $15 \mathrm{~g} 16850$ & -2.35 & 0.015 Haloacid dehalogenase-like hydrolase (HAD) superfamily protein \\
\hline
\end{tabular}


Table S3. Biological categories that are regulated in the S562L shoot tip in comparison to wild type shoot tip as analysed by Mapman (Benjamini Hochberg-corrected; $P<0.05$ ).

\begin{tabular}{|c|c|c|c|}
\hline Bin & Name & Elements & p-value \\
\hline \multicolumn{4}{|c|}{ Photosynthesis } \\
\hline 1 & PS & 317 & 0 \\
\hline 1.1 & PS.light reaction & 220 & 0 \\
\hline 1.1 .1 & PS.light reaction. photosystem II & 98 & 0 \\
\hline 1.1 .1 .1 & PS.light reaction. photosystem II.LHC-II & 38 & $1.46223 \mathrm{E}-10$ \\
\hline 1.1 .1 .2 & PS.light reaction. photosystem II.PSII polypeptide subunits & 60 & $1.28332 \mathrm{E}-06$ \\
\hline 1.1 .2 & PS.light reaction. photosystem I & 39 & $1.82784 \mathrm{E}-07$ \\
\hline 1.1.2.2 & PS.light reaction. photosystem I.PSI polypeptide subunits & 31 & $9.16001 \mathrm{E}-08$ \\
\hline 1.1 .5 & PS.light reaction.other electron carrier (ox/red) & 33 & 0.042731782 \\
\hline \multicolumn{4}{|c|}{$\begin{array}{l}\text { Major } \mathrm{CHO} \\
\text { metabolism }\end{array}$} \\
\hline 2.1 .2 & major $\mathrm{CHO}$ metabolism.synthesis.starch & 56 & 0.019806396 \\
\hline 2.1 .2 .1 & major $\mathrm{CHO}$ metabolism.synthesis.starch.AGPase & 17 & 0.011872219 \\
\hline 2.1.2.2 & major $\mathrm{CHO}$ metabolism.synthesis.starch.starch synthase & 15 & 0.015657959 \\
\hline 2.2 & major $\mathrm{CHO}$ metabolism.degradation & 147 & 0.033712098 \\
\hline 2.2.1.3 & major $\mathrm{CHO}$ metabolism.degradation.sucrose.invertases & 37 & 0.028318178 \\
\hline 2.2.1.3.2 & major $\mathrm{CHO}$ metabolism.degradation.sucrose.invertases.cell wall & 22 & 0.000328236 \\
\hline 2.2.1.3.3 & major $\mathrm{CHO}$ metabolism.degradation.sucrose.invertases.vacuolar & 7 & 0.007550217 \\
\hline 2.2 .2 & major $\mathrm{CHO}$ metabolism.degradation.starch & 58 & 0.043862952 \\
\hline 2.2.2.1 & major $\mathrm{CHO}$ metabolism. degradation.starch.starch cleavage & 26 & 0.021405036 \\
\hline
\end{tabular}

\section{Minor $\mathrm{CHO}$}

metabolism

\begin{tabular}{llll}
\hline 3.1 & minor CHO metabolism.raffinose family & 19 & 0.014279496 \\
3.1 .2 & minor CHO metabolism.raffinose family.raffinose synthases & 12 & 0.003851643 \\
3.1 .2 .2 & minor CHO metabolism.raffinose family.raffinose synthases.putative & 12 & 0.003851643 \\
3.2 .2 & minor CHO metabolism.trehalose.TPP & 22 & 0.033634009 \\
3.4 .3 & minor CHO metabolism.myo-inositol.InsP Synthases & 4 & 0.040258978 \\
\hline Cell wall & & & \\
\hline 10 & cell wall & 875 & $9.90407 \mathrm{E}-06$ \\
10.5 .3 & cell wall.cell wall proteins.LRR & 22 & 0.020416261 \\
10.7 & cell wall.modification & 153 & 0.009841828 \\
10.8 & cell wall.pectin*esterases & 153 & 0.006763777 \\
10.8 .1 & cell wall.pectin*esterases.PME & 130 & 0.027926432 \\
\hline
\end{tabular}

Lipid metabolism

\begin{tabular}{llcc}
\hline 11.9 .3 .4 & lipid metabolism.lipid degradation.lysophospholipases.phospholipase A2 & 6 & 0.021694885 \\
\hline $\begin{array}{l}\text { Amino acid } \\
\text { metabolism }\end{array}$ & & 11 & 0.015036573 \\
\hline 13.1 .3 .6 & amino acid metabolism.synthesis.aspartate family.misc & 11 & 0.015036573 \\
13.1 .3 .6 .1 & amino acid metabolism.synthesis.aspartate family.misc.homoserine & 8 & 0.015473113 \\
13.1 .3 .6 .1 .1 & amino acid metabolism.synthesis.aspartate family.misc.homoserine.aspartate & 8 & \\
\hline S- assimilation & kinase & 3 & 0.048354292 \\
\hline 14.2 & S-assimilation.APR & & \\
\hline
\end{tabular}


Table S3. Continued.

\begin{tabular}{|c|c|c|c|}
\hline \multicolumn{4}{|l|}{$\begin{array}{l}\text { Secondary } \\
\text { metabolism }\end{array}$} \\
\hline 16 & secondary metabolism & 761 & $2.10308 \mathrm{E}-09$ \\
\hline 16.1 & secondary metabolism.isoprenoids & 192 & 0.009275191 \\
\hline 16.1 .3 & secondary metabolism.isoprenoids.tocopherol biosynthesis & 24 & 0.000171833 \\
\hline 16.1.3.2 & $\begin{array}{l}\text { secondary metabolism.isoprenoids.tocopherol biosynthesis.homogentisate } \\
\text { phytyltransferase }\end{array}$ & 12 & 0.003851643 \\
\hline 16.2 & secondary metabolism. phenylpropanoids & 261 & $6.13238 \mathrm{E}-05$ \\
\hline 16.2.1 & secondary metabolism. phenylpropanoids.lignin biosynthesis & 118 & $5.45265 \mathrm{E}-07$ \\
\hline 16.2.1.1 & secondary metabolism.phenylpropanoids.lignin biosynthesis.PAL & 8 & 0.000396601 \\
\hline 16.2.1.3 & secondary metabolism.phenylpropanoids.lignin biosynthesis. $4 \mathrm{CL}$ & 31 & 0.011872219 \\
\hline 16.2.1.6 & secondary metabolism. phenylpropanoids.lignin biosynthesis. CCoAOMT & 15 & 0.036064324 \\
\hline 16.8 & secondary metabolism.flavonoids & 155 & $6.45017 \mathrm{E}-07$ \\
\hline 16.8 .2 & secondary metabolism. flavonoids.chalcones & 26 & $2.09935 \mathrm{E}-08$ \\
\hline 16.8 .5 & secondary metabolism. flavonoids.isoflavonols & 22 & 0.000638941 \\
\hline \multicolumn{4}{|c|}{ Hormone metabolism } \\
\hline 17 & hormone metabolism & 1302 & $2.80432 \mathrm{E}-08$ \\
\hline 17.5 & hormone metabolism.ethylene & 430 & $1.19416 \mathrm{E}-05$ \\
\hline 17.5 .2 & hormone metabolism.ethylene.signal transduction & 178 & 0.000622743 \\
\hline 17.6 & hormone metabolism.gibberelin & 101 & 0.009275191 \\
\hline 17.7 & hormone metabolism.jasmonate & 72 & 0.00068077 \\
\hline 17.7.1 & hormone metabolism.jasmonate.synthesis-degradation & 70 & 0.000507643 \\
\hline 17.7.1.2 & hormone metabolism.jasmonate.synthesis-degradation.lipoxygenase & 45 & 0.009861992 \\
\hline 17.7.1.5 & $\begin{array}{l}\text { hormone metabolism.jasmonate.synthesis-degradation. } 12 \text { 2-Oxo-PDA- } \\
\text { reductase }\end{array}$ & 12 & 0.014129403 \\
\hline \multicolumn{4}{|l|}{ Stress } \\
\hline 20 & stress & 1776 & $7.21114 \mathrm{E}-07$ \\
\hline 20.1 & stress.biotic & 979 & 0 \\
\hline 20.1 .7 & stress.biotic.PR-proteins & 711 & 0 \\
\hline 20.2 & stress.abiotic & 775 & 0.013788265 \\
\hline 20.2.1 & stress.abiotic.heat & 375 & $5.46072 \mathrm{E}-10$ \\
\hline \multicolumn{4}{|c|}{ Redox regulation } \\
\hline 21 & redox.regulation & 405 & 0.005916683 \\
\hline 21.4 & redox.glutaredoxins & 89 & 0.029935211 \\
\hline
\end{tabular}

Polyamine

metabolism

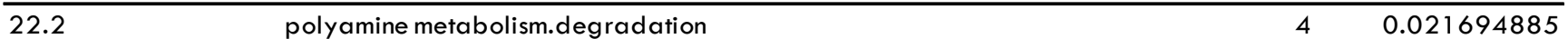

22.2.1

polyamine metabolism.degradation. polyamin oxidase

$4 \quad 0.021694885$

Nucleotide

metabolism

\begin{tabular}{|c|c|c|c|}
\hline 23 & nucleotide metabolism & 269 & 0.007504987 \\
\hline 23.1 & nucleotide metabolism.synthesis & 66 & 0.000192645 \\
\hline 23.1 .1 & nucleotide metabolism.synthesis.pyrimidine & 26 & 0.009342322 \\
\hline 23.1 .1 .1 & $\begin{array}{l}\text { nucleotide metabolism.synthesis.pyrimidine.carbamoyl phosphate } \\
\text { synthetase }\end{array}$ & 7 & 0.041272522 \\
\hline 23.1 .2 & nucleotide metabolism.synthesis.purine & 28 & 0.025728984 \\
\hline
\end{tabular}

Biodegradation of

Xenobiotics

24.2

Biodegradation of Xenobiotics.lactoylglutathione lyase

$27 \quad 0.048107793$ 
Table S3. Continued.

\begin{tabular}{|c|c|c|c|}
\hline \multicolumn{4}{|l|}{ RNA } \\
\hline 27 & RNA & 6310 & $1.69051 \mathrm{E}-36$ \\
\hline 27.1 & RNA.processing & 582 & $4.64734 \mathrm{E}-33$ \\
\hline 27.1 .1 & RNA.processing.splicing & 101 & $5.37497 \mathrm{E}-06$ \\
\hline 27.1 .2 & RNA.processing. RNA helicase & 73 & $3.60128 \mathrm{E}-12$ \\
\hline 27.2 & RNA.transcription & 232 & 0.00022923 \\
\hline 27.3 & RNA.regulation of transcription & 5289 & $9.85113 \mathrm{E}-13$ \\
\hline 27.3 .25 & RNA.regulation of transcription.MYB domain transcription factor family & 667 & $1.55764 \mathrm{E}-11$ \\
\hline 27.3 .32 & RNA.regulation of transcription. WRKY domain transcription factor family & 174 & 0 \\
\hline 27.3.44 & RNA.regulation of transcription. Chromatin Remodeling Factors & 102 & $3.61765 \mathrm{E}-06$ \\
\hline 27.3 .50 & RNA.regulation of transcription. General Transcription & 60 & $8.02228 \mathrm{E}-05$ \\
\hline 27.3 .52 & RNA.regulation of transcription. Global transcription factor group & 29 & 0.015473113 \\
\hline 27.3 .54 & RNA.regulation of transcription. Histone acetyltransferases & 24 & 0.013788265 \\
\hline 27.3 .57 & RNA.regulation of transcription.JUMONJI family & 32 & 0.014129403 \\
\hline 27.3 .63 & RNA.regulation of transcription. PHD finger transcription factor & 39 & 0.009861992 \\
\hline 27.3 .64 & RNA.regulation of transcription.PHOR 1 & 39 & $1.17597 \mathrm{E}-06$ \\
\hline 27.3 .67 & RNA.regulation of transcription.putative transcription regulator & 397 & $1.95682 \mathrm{E}-11$ \\
\hline 27.3 .69 & RNA.regulation of transcription.SET-domain transcriptional regulator family & 77 & 0.033634009 \\
\hline 27.3 .99 & RNA.regulation of transcription. unclassified & 621 & $2.00383 \mathrm{E}-06$ \\
\hline 27.4 & RNA.RNA binding & 267 & $1.14682 \mathrm{E}-12$ \\
\hline \multicolumn{4}{|l|}{ DNA } \\
\hline 28 & DNA & 939 & $4.19444 \mathrm{E}-18$ \\
\hline 28.1 & DNA.synthesis/chromatin structure & 567 & $8.43108 \mathrm{E}-16$ \\
\hline 28.1 .3 & DNA.synthesis/chromatin structure. histone & 71 & $4.61178 \mathrm{E}-08$ \\
\hline 28.2 & DNA repair & 116 & 0.000367641 \\
\hline \multicolumn{4}{|l|}{ Protein } \\
\hline 29 & protein & 6420 & $2.50503 \mathrm{E}-26$ \\
\hline 29.1 & protein.aa activation & 135 & $2.80432 \mathrm{E}-08$ \\
\hline 29.1 .30 & protein.aa activation. pseudouridylate synthase & 24 & 0.022243842 \\
\hline 29.2 & protein.synthesis & 976 & $3.46656 \mathrm{E}-17$ \\
\hline 29.2 .1 & protein.synthesis.ribosomal protein & 670 & 0.001970238 \\
\hline 29.2.1.1.1.1 & protein.synthesis.ribosomal protein.prokaryotic.chloroplast. 30 S subunit & 31 & 0.009275191 \\
\hline 29.2.1.2 & protein.synthesis.ribosomal protein.eukaryotic & 428 & 0.000668567 \\
\hline 29.2.1.2.1 & protein.synthesis.ribosomal protein.eukaryotic. 40 S subunit & 163 & 0.006166941 \\
\hline 29.2.2 & protein.synthesis.misc ribososomal protein & 22 & 0.007251695 \\
\hline 29.2.2.50 & protein.synthesis.misc ribososomal protein. BRIX & 11 & 0.007550217 \\
\hline 29.2 .3 & protein.synthesis.initiation & 184 & $7.66744 \mathrm{E}-16$ \\
\hline 29.2 .4 & protein.synthesis.elongation & 66 & 0.004180482 \\
\hline 29.2 .99 & protein.synthesis.misc & 12 & 0.037356552 \\
\hline 29.3 & protein.targeting & 490 & $1.60382 \mathrm{E}-08$ \\
\hline 29.3.1 & protein.targeting.nucleus & 98 & $1.60564 \mathrm{E}-08$ \\
\hline 29.3 .3 & protein.targeting.chloroplast & 66 & 0.022901299 \\
\hline 29.3.4.2 & protein.targeting.secretory pathway.golgi & 24 & 0.019980876 \\
\hline 29.4.1 & protein.postranslational modification.kinase & 550 & $1.31382 \mathrm{E}-07$ \\
\hline 29.4 .1 .57 & $\begin{array}{l}\text { protein.postranslational modification.kinase.receptor like cytoplasmatic } \\
\text { kinase VII }\end{array}$ & 515 & $2.97425 \mathrm{E}-07$ \\
\hline 29.5 & protein.degradation & 2751 & 0.000556946 \\
\hline 29.5 .11 & protein.degradation.ubiquitin & 1824 & 0.000367641 \\
\hline 29.5 .11 .5 & protein.degradation.ubiquitin.ubiquitin protease & 72 & $4.92242 \mathrm{E}-08$ \\
\hline 29.5 .11 .20 & protein.degradation.ubiquitin.proteasom & 151 & $2.00383 \mathrm{E}-06$ \\
\hline
\end{tabular}


Table S3. Continued.

\section{Signalling}

30

30.1

30.2

30.2.11

30.2 .17

30.2.24

30.2 .25

30.2 .99

30.3

30.5

Cell

31.1

31.2 signalling

signalling.in sugar and nutrient physiology

signalling.receptor kinases

signalling.receptor kinases.leucine rich repeat XI

signalling.receptor kinases.DUF 26

signalling.receptor kinases.S-locus glycop rotein like

signalling.receptor kinases.wall associated kinase

signalling.receptor kinases.misc

signalling.calcium

signalling.G-proteins

cell.organisation

cell.division
2836

$98 \quad 0.037356552$

1307

$365 \quad 2.49818 \mathrm{E}-07$

554

0

$66 \quad 0.000142501$

390.028132661

$219 \quad 7.58628 \mathrm{E}-06$

$496 \quad 1.02576 \mathrm{E}-07$

$482 \quad 0.004180482$

$843 \quad 0.008218999$

$\begin{array}{ll}161 & 0.001000067\end{array}$

Development

33.1

development.storage proteins

$89 \quad 1.26332 \mathrm{E}-05$

Transport

34.3

transport.amino acids

$180 \quad 0.002846344$

34.9

transport.metabolite transporters at the mitochondrial

membrane

$141 \quad 0.015657959$

34.19

transport.Major Intrinsic Proteins

$96 \quad 9.49911 \mathrm{E}-05$

34.19 .2

transport.Major Intrinsic Proteins. TIP

370.000233643

34.22

transport.cyclic nucleotide or calcium regulated channels

410.003764466

34.99

transport.misc

$639 \quad 1.5495 \mathrm{E}-18$ 
Table S4. Biological categories that are regulated in the S562L root tip in comparison to wild type root tip as analysed by Mapman (Benjamini Hochberg-corrected; $P<0.05$ ).

\begin{tabular}{|c|c|c|c|}
\hline Bin & name & elements & p-value \\
\hline \multicolumn{4}{|c|}{ Photosynthesis } \\
\hline 1 & PS & 317 & $2.23 \mathrm{E}-06$ \\
\hline 1.1 & PS.light reaction & 220 & $1.56 \mathrm{E}-08$ \\
\hline 1.1 .1 & PS.light reaction. photosystem II & 98 & $1.88 \mathrm{E}-06$ \\
\hline 1.1 .1 .1 & PS.light reaction. photosystem II.LHC-II & 38 & $4.79 \mathrm{E}-04$ \\
\hline 1.1 .1 .2 & PS.light reaction. photosystem II.PSII polypeptide subunits & 60 & 0.006735025 \\
\hline 1.1 .2 & PS.light reaction. photosystem I & 39 & $7.10 \mathrm{E}-04$ \\
\hline 1.1 .2 .2 & PS.light reaction.photosystem I.PSI polypeptide subunits & 31 & $5.16 \mathrm{E}-05$ \\
\hline \multicolumn{4}{|c|}{ Fermentation } \\
\hline 5.2 & fermentation. PDC & 8 & 0.01995843 \\
\hline \multicolumn{4}{|l|}{ Cell wall } \\
\hline 10 & cell wall & 875 & 0.001131608 \\
\hline 10.6 & cell wall degradation & 254 & 0.004153439 \\
\hline \multicolumn{4}{|c|}{ Lipid metabolism } \\
\hline 11.9 & lipid metabolism.l ipid degradation & 271 & 0.0015716 \\
\hline 11.9 .2 & lipid metabolism.lipid degradation.l ipases & 113 & 0.00294316 \\
\hline 11.9 .2 .1 & lipid metabolism.lipid degradation.lipases.triacylglycerol lipase & 89 & 0.038454121 \\
\hline
\end{tabular}

\section{Amino acid}

metabolism

\begin{tabular}{|c|c|c|c|}
\hline 13.2 & amino acid metabolism. degradation & 156 & 0.018542453 \\
\hline 13.2.3 & amino acid metabolism. degradation.aspartate family & 45 & 0.046371554 \\
\hline 13.2 .4 & amino acid metabolism. degradation.branched chain group & 31 & 0.002102358 \\
\hline \multicolumn{4}{|c|}{$\begin{array}{l}\text { Secondary } \\
\text { metabolism }\end{array}$} \\
\hline 16 & secondary metabolism & 761 & 0.034592476 \\
\hline 16.2.1 & secondary metabolism. phenylpropanoids.lignin biosynthesis & 118 & 0.005204386 \\
\hline 16.2.1.1 & secondary metabolism.phenylpropanoids.lignin biosynthesis.PAL & 8 & 0.014817383 \\
\hline 16.2.1.3 & secondary metabolism.phenylpropanoids.lignin biosynthesis. $4 \mathrm{CL}$ & 31 & 0.014331695 \\
\hline 16.8 & secondary metabolism.flavonoids & 155 & 0.011867805 \\
\hline 16.8 .2 & secondary metabolism. flavonoids.chalcones & 26 & 0.001215041 \\
\hline \multicolumn{4}{|c|}{$\begin{array}{l}\text { Hormone } \\
\text { metabolism }\end{array}$} \\
\hline 17 & hormone metabolism & 1302 & 0.004747464 \\
\hline 17.2.2 & hormone metabolism.auxin.signal transduction & 54 & 0.021272135 \\
\hline 17.5 .2 & hormone metabolism.ethylene.signal transduction & 178 & 0.04073287 \\
\hline 17.7 & hormone metabolism.jasmonate & 72 & 0.033698515 \\
\hline \multicolumn{4}{|l|}{ 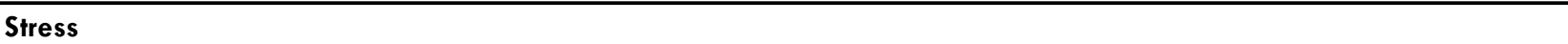 } \\
\hline 20.1 & stress.biotic & 979 & 0.025578528 \\
\hline 20.1 .7 .6 & stress.biotic.PR-proteins. proteinase inhibitors & 34 & 0.002102358 \\
\hline 20.2 & stress.abiotic & 775 & 0.002668161 \\
\hline 20.2.1 & stress.abiotic.heat & 375 & $5.16 \mathrm{E}-05$ \\
\hline 20.2 .3 & stress.abiotic.drought/salt & 129 & 0.033698515 \\
\hline
\end{tabular}


Table S4. Continued.

Redox regulation

\begin{tabular}{|c|c|c|c|}
\hline 21.4 & redox.glutaredoxins & 89 & 0.033698515 \\
\hline \multicolumn{4}{|l|}{ Nucleotide } \\
\hline \multicolumn{4}{|l|}{ metabolism } \\
\hline \multirow[t]{2}{*}{23.1 .2} & nucleotide metabolism.synthesis.purine & 28 & 0.034892781 \\
\hline & nucleotide & & \\
\hline 23.1 .2 .1 & metabolism.synthesis.purine.amidophosphoribosyltransferase & 5 & 0.021645967 \\
\hline \multicolumn{4}{|l|}{ Misc } \\
\hline 26.2 & misc.UDP glucosyl and glucoronyl transferases & 502 & 0.011867805 \\
\hline 26.1 & misc.cytochrome P450 & 398 & 0.007547013 \\
\hline 26.12 & misc.peroxidases & 185 & $2.37 \mathrm{E}-05$ \\
\hline \multicolumn{4}{|l|}{ RNA } \\
\hline 27 & RNA & 6310 & $7.58 \mathrm{E}-05$ \\
\hline 27.3 & RNA.regulation of transcription & 5289 & 0.014817383 \\
\hline \multirow[t]{2}{*}{27.3 .4} & RNA.regulation of transcription.ARF, Auxin Response Factor family & 57 & 0.002008989 \\
\hline & RNA.regulation of transcription.CCAAT box binding factor family, & & \\
\hline \multirow[t]{2}{*}{27.3 .14} & HAP2 & 21 & 0.008713324 \\
\hline & RNA.regulation of transcription.Trihelix, Triple-Helix transcription & & \\
\hline \multirow[t]{2}{*}{27.3 .30} & factor family & 64 & 0.008713324 \\
\hline & RNA.regulation of transcription. WRKY domain transcription factor & & \\
\hline 27.3 .32 & family & 174 & $4.18 \mathrm{E}-11$ \\
\hline 27.3 .64 & RNA.regulation of transcription.PHOR 1 & 39 & $1.05 \mathrm{E}-04$ \\
\hline 27.3 .80 & RNA.regulation of transcription.zf-HD & 43 & 0.002668161 \\
\hline 27.3 .99 & RNA.regulation of transcription.unclassified & 621 & $3.38 \mathrm{E}-07$ \\
\hline \multicolumn{4}{|l|}{ DNA } \\
\hline 28.1 .3 & DNA.synthesis/chromatin structure.histone & 71 & $2.24 \mathrm{E}-08$ \\
\hline \multicolumn{4}{|l|}{ Protein } \\
\hline 29.2 & protein.synthesis & 976 & $2.44 \mathrm{E}-09$ \\
\hline 29.2 .1 & protein.synthesis.ribosomal protein & 670 & 0 \\
\hline 29.2 .1 .2 & protein.synthesis.ribosomal protein.eukaryotic & 428 & 0 \\
\hline 29.2.1.2.1 & protein.synthesis.ribosomal protein.eukaryotic. $40 \mathrm{OS}$ subunit & 163 & $1.76 \mathrm{E}-08$ \\
\hline 29.2.1.2.2 & protein.synthesis.ribosomal protein.eukaryotic. $60 \mathrm{~S}$ subunit & 265 & $3.25 \mathrm{E}-13$ \\
\hline 29.2 .3 & protein.synthesis.initiation & 184 & 0.007187207 \\
\hline 29.3 & protein.targeting & 490 & 0.00294316 \\
\hline 29.3.4 & protein.targeting.secretory pathway & 237 & $2.13 \mathrm{E}-06$ \\
\hline 29.3 .4 .2 & protein.targeting.secretory pathway.golgi & 24 & 0.001431831 \\
\hline 29.5 & protein.degradation & 2751 & 0.014770075 \\
\hline 29.5 .11 & protein.degradation.ubiquitin & 1824 & 0.034568824 \\
\hline 29.5 .11 .5 & protein.degradation.ubiquitin.ubiquitin protease & 72 & 0.003802264 \\
\hline 29.5 .11 .20 & protein.degradation.ubiquitin. proteasom & 151 & $5.16 \mathrm{E}-05$ \\
\hline 29.7 & protein.glycosylation & 58 & 0.029399721 \\
\hline \multicolumn{4}{|l|}{ Signalling } \\
\hline 30 & signalling & 2836 & 0.008713324 \\
\hline 30.2 & signalling.receptor kinases & 1307 & $2.24 \mathrm{E}-08$ \\
\hline 30.2 .17 & signalling.receptor kinases.DUF 26 & 554 & $2.26 \mathrm{E}-12$ \\
\hline 30.2 .24 & signalling.receptor kinases.S-locus glycoprotein like & 66 & 0.010926445 \\
\hline 30.2 .25 & signalling.receptor kinases.wall associated kinase & 39 & 0.007347366 \\
\hline 30.2 .99 & signalling.receptor kinases.misc & 219 & 0.018034925 \\
\hline \multicolumn{4}{|l|}{ Cell } \\
\hline 31 & cell & 1584 & $6.23 \mathrm{E}-05$ \\
\hline 31.4 & cell.vesicle transport & 336 & $2.13 \mathrm{E}-06$ \\
\hline \multicolumn{4}{|l|}{ Development } \\
\hline 33.1 & development.storage proteins & 89 & $1.06 \mathrm{E}-04$ \\
\hline \multicolumn{4}{|l|}{ Transport } \\
\hline 34.19 & transport.Major Intrinsic Proteins & 96 & 0.002528114 \\
\hline
\end{tabular}

